Article

\title{
Enhanced Oceanic Environmental Responses and Feedbacks to Super Typhoon Nida (2009) during the Sudden-Turning Stage
}

\author{
Jiagen Li ${ }^{1}\left(\mathbb{D}\right.$, Yuanjian Yang ${ }^{2,3}$, Guihua Wang ${ }^{4}$, Hao Cheng ${ }^{1}$ and Liang Sun ${ }^{1, *}$ \\ 1 School of Earth and Space Sciences, University of Science and Technology of China, Hefei 230000, China; \\ ljg123@mail.ustc.edu.cn (J.L.); ch0127@mail.ustc.edu.cn (H.C.) \\ 2 School of Atmospheric Physics, Nanjing University of Information Science and Technology, \\ Nanjing 210000, China; yyj1985@nuist.edu.cn \\ 3 Guangdong Key Laboratory of Ocean Remote Sensing, South China Sea Institute of Oceanology, \\ Chinese Academy of Sciences, Guangzhou 510000, China \\ 4 Department of Atmospheric and Oceanic Sciences, Fudan University, Shanghai 200000, China; \\ wanggh@fudan.edu.cn \\ * Correspondence: sunl@ustc.edu.cn; Tel.: +86-0551-6360-6723
}

check for updates

Citation: Li, J.; Yang, Y.; Wang, G.; Cheng, H.; Sun, L. Enhanced Oceanic Environmental Responses and Feedbacks to Super Typhoon Nida (2009) during the Sudden-Turning Stage. Remote Sens. 2021, 13, 2648. https://doi.org/10.3390/rs13142648

Academic Editor: Gad Levy

Received: 28 May 2021

Accepted: 1 July 2021

Published: 6 July 2021

Publisher's Note: MDPI stays neutral with regard to jurisdictional claims in published maps and institutional affiliations.

Copyright: (c) 2021 by the authors. Licensee MDPI, Basel, Switzerland. This article is an open access article distributed under the terms and conditions of the Creative Commons Attribution (CC BY) license (https:// creativecommons.org/licenses/by/ $4.0 /)$.

\begin{abstract}
The ocean surface and subsurface biophysical responses and their feedbacks to super typhoon Nida were comprehensively investigated based on a substantial dataset of multiple-satellite observations, Argo profiles, and reanalysis data. Nida experienced two Category 5 stages: a rapid intensification stage that was fast moving along a straight-line track, and a rapid weakening stage that was slowly moving along a sharp-left sudden-turning track. During the straight-line stage, Nida caused an average sea surface temperature (SST) cooling of $1.44{ }^{\circ} \mathrm{C}$ and a chlorophyll- $a$ (chl- $a$ ) concentration increase of $0.03 \mathrm{mg} \mathrm{m}^{-3}$. During the sudden-turning stage, cyclonic sudden-turning induced a strong cold cyclonic eddy (SSHA $<-60 \mathrm{~cm}$ ) by strong upwelling, which caused the maximum SST cooling of $6.68{ }^{\circ} \mathrm{C}$ and a long-lasting chl- $a$ bloom of $0.6 \mathrm{mg} \mathrm{m}^{-3}$ on the left-hand side of the track, resulting in substantial impacts on the ocean ecological environment. Furthermore, the enhanced ocean cold wake and the longer air-sea interaction in turn decreased the average inner-core SST of $4{ }^{\circ} \mathrm{C}$ and the corresponding enthalpy flux of $780 \mathrm{~W} \mathrm{~m}^{-2}$, which induced a notable negative feedback to the typhoon intensity by weakening it from Category 5 to Category 2. The left bias response and notable negative feedback are special due to sharp-left sudden-turning of typhoon. Comparing with the previously found slow translation speed $\left(\sim 4 \mathrm{~m} \mathrm{~s}^{-1}\right)$ of significant ocean response, the negative feedback requires even more restriction of translation speed $\left(<2 \mathrm{~m} \mathrm{~s}^{-1}\right)$ and sharp sudden-turning could effectively relax restrictions by making equivalent translation speed lower and air-sea interaction time longer. Our findings point out that there are some unique features in ocean-typhoon interactions under sudden-turning and/or lingering tracks comparing with ordinary tracks.
\end{abstract}

Keywords: super typhoon Nida; air-sea interaction; oceanic environmental responses; left bias; negative feedbacks; cold wake; chlorophyll- $a$ bloom

\section{Introduction}

Tropical cyclones are generated mainly near the tropics, known as typhoons in the northwestern Pacific (NWP) and hurricanes in the Atlantic, which can cause notable dynamical responses of the upper ocean [1]. The most significant one might be the cold wake often seen along the typhoon track [1] due to ocean surface enthalpy fluxes, vertical mixing, and upwelling [2-4]. Within the cold wake, there may also be marine phytoplankton blooms [5,6].

Since the cold wake caused by a typhoon can cool the sea surface temperature (SST) [7-9], it may have a negative feedback effect on the passing typhoon [10]. However, there is a long-term debate as to whether such a cold wake can immediately induce a 
significant negative feedback effect on the typhoon intensity itself [11]. For example, Chang and Anthes [12] concluded that the cold wake does not significantly affect the intensity of the typhoon itself under a typical moving speed, but Sutyrin and Khain [13] suggested that the cold wake could induce a significant negative feedback effect on the typhoon intensity.

In general, the ocean's negative feedback to typhoon intensity first requires that the typhoon can cause significant SST cooling. This is because a decrease in SST, especially an inner-core SST change, has a substantial impact on the observed typhoon intensity [14]. Emanuel [15] suggested that when the inner-core SST drops by $2.5^{\circ} \mathrm{C}$, the storm could terminate, and even a drop of $0.5^{\circ} \mathrm{C}$ can have a substantial impact on the storm intensity. Second, negative feedback of the ocean to typhoon intensity also requires the condition that the typhoon has a long residence time over the SST cooling area. As there is a lag time in the response of a typhoon to the SST [12,16], it needs sufficient time to be affected by the cold wake. Therefore, the speed of the typhoon [17] and the forcing time [18] become important factors alongside other related factors including the SST, ocean mixed-layer depth (MLD), ocean stratification, typhoon size, and latitude [19].

Although these theoretical studies are instructive for understanding ocean-typhoon negative feedback, they are largely based on certain idealized conditions, such as a homogeneous spatial distribution of the background environment or the existence of idealized mesoscale eddies $[20,21]$ and a straight-line typhoon track $[12,13]$. In the actual process of typhoon-ocean interaction, the ocean environment, typhoon track, and typhoon intensity are changeable. In particular, some typhoons turn sharply during their passage, which introduces new factors of change into the study of typhoon-ocean interaction. This type of typhoon-ocean interaction process caused by typhoon motion (nonuniform linear motion) is of great significance towards fully understanding typhoon-ocean interactions.

The NWP has the highest concentration of tropical cyclones in the world. According to the Joint Typhoon Warning Center (JTWC), super typhoon is defined as the typhoon with maximum sustained wind (MSW) exceeding $130 \mathrm{kts}$. Typhoon Nida was the twentysixth tropical storm and fourth super typhoon of the 2009 NWP typhoon season. Figure 1 shows the lifespan of typhoon Nida based on the best-track data from the JTWC. Nida generated on 21 November 2009 and achieved typhoon intensity with the MSW of $65 \mathrm{kts}$ on 24 November. Thereafter, Nida kept fast moving northwest along a straight-line track with the moving speed of $6 \mathrm{~m} \mathrm{~s}^{-1}$, and rapidly intensified to $155 \mathrm{kts}$ on 25 November. It is surprised that Nida intensified by $90 \mathrm{kts}$ within $24 \mathrm{~h}$ during the straight-line (SL) stage, which was three times greater than the definition of rapid intensification [22]. If Nida continued to move and develop in accordance with this trend, it was likely to hit China or Japan in the next few days and bring heavy disasters. However, Nida suddenly turned left on 28 November and weakened rapidly from $150 \mathrm{kts}$ to $90 \mathrm{kts}$ during the sudden-turning (ST) stage from 28 November to 30 November. After that, Nida weakened to a tropical storm on 2 December and disappeared on 3 December, and thus the populated areas on Northwest Pacific coast avoided a typhoon in the end.

In this paper, we focused on the interaction between ocean and Nida during the ST stage by comparing the ocean responses and feedback during the SL Stage. The scientific breakthroughs and new discoveries in this paper mainly include following three points. Firstly, the typical ocean SST response is right bias due to clockwise wind stress, as firstly pointed out by Price [1]. Some oceanic environments (e.g., previously existed cold eddy in left side) may shift this right bias (e.g., Zheng et al., [23]). This study showed a left bias response purely due to typhoon left-side sharp turning. To our best knowledge, this new phenomenon is has not been reported and explained before. Secondly, when a typhoon turns sharply, the equivalent moving speed of the typhoon will be slower, and the typhoon's forcing time on the ocean will be longer, resulting in more intense marine biological and physical responses. Thirdly and the most importantly, there was a long-term controversial theoretical problem "whether typhoon inducing cold wake can immediately induce a significant negative feedback effect on the typhoon intensity itself". Comparing with the previously found slow translation speed $\left(\sim 4 \mathrm{~m} \mathrm{~s}^{-1}\right)$ of significant ocean response, 
we showed with observation that such negative feedback could only work under very restricted conditions with typical translation speed $<2 \mathrm{~m} \mathrm{~s}^{-1}$ and we pointed out that sharp sudden-turning could effectively relax restrictions by making equivalent translation speed lower and air-sea interaction time longer. Comparing with speed, both the intensity and size play relatively minor roles. Our new findings provide positive evidence that enhanced oceanic environmental responses and feedbacks can occur under sudden-turning tracks, furtherly, we can improve our ability to forecast the variation of marine environment and rapidly change of typhoon intensity through typhoon track.

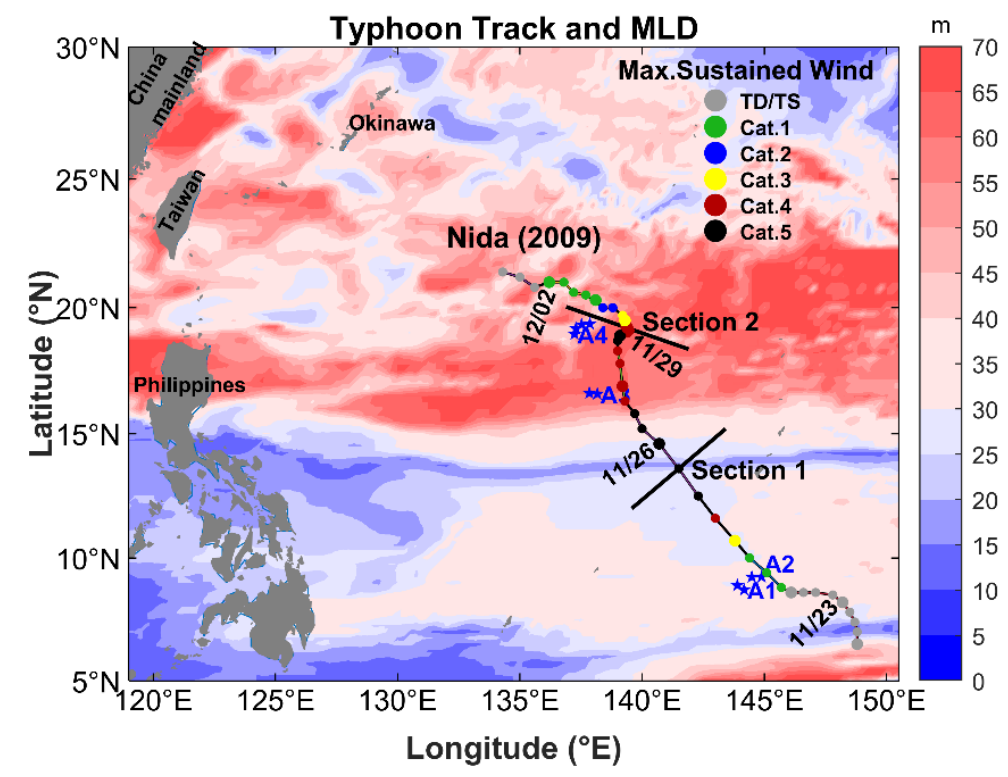

Figure 1. Best track of typhoon Nida (2009) from the JTWC. The blue stars denote the positions and trajectory of Argo floats (A1 to A4 are floats 5902121, 5901213, 5900976, and 2900401). The track line color indicates the MSW speed of the typhoon. The background pattern is the MLD field on 22 November before the passage of typhoon. The two black sections indicate the location of the strongest intensity (section 1) and maximum turning (section 2).

\section{Materials and Methods}

\subsection{Typhoon Track Data}

Each best-track file from JTWC contains the tropical cyclone center locations, the central pressure and the maximum sustained wind (MSW) speeds, the wind radius, and the radii of the specified winds $\left(17,25,33\right.$, or $\left.51 \mathrm{~m} \mathrm{~s}^{-1}\right)$ for four quadrants, at $6 \mathrm{~h}$ intervals. In this study, we defined the turning angle of a typhoon as the azimuth change of the path in the $12 \mathrm{~h}$ before and $12 \mathrm{~h}$ after a certain point (turn left, positive; turn right, negative).

Besides, we counted the translation speed and turning angle of typhoons between 1981 and 2018 based on JTWC dataset in order to count the proportion of turning typhoons and prove the importance of our research in the discussion.

\subsection{Data}

\subsubsection{Sea Surface Temperature}

We used daily SST products that were integrated with microwave and infrared optimally interpolated (MW_IR_OI) data from Remote Sensing Systems (RSS) (www.remss. com, (accessed on 1 April 2021)). The MW_IR_OI data products used included the Tropical Rainfall Measuring Mission (TRMM) Microwave Imager, the Advanced Microwave Scanning Radiometer, the WindSat Polarimetric Radiometer, and the Global Precipitation Measurement (GPM) microwave imager SST data. Also included were the SST data detected in the infrared band by the Moderate-Resolution Imaging Spectroradiometer onboard the Terra and Aqua satellites of the Earth Observation Satellite series and the 
Visible/Infrared Imaging Radiometer Suite onboard the Suomi National Polar-Orbiting Partnership. These instruments are suitable for analyzing the response of the upper ocean to the passage of typhoons because microwave imagers and radiometers are able to penetrate clouds and the infrared channel of radiometers onboard polar-orbiting satellites has a high spatial resolution [24]. In this study, we used daily data with a spatial resolution of $9 \times 9 \mathrm{~km}$.

\subsubsection{Sea Surface Salinity}

The sea surface salinity (SSS) data were from the three-dimensional global ocean reanalysis product produced by the Copernicus Marine and Environmental Monitoring Service Global Monitoring and Forecasting Centre (http:/ / marine.copernicus.eu/servicesportfolio/access-to-products/, (accessed on 1 April 2021)). The products assessed in this study are referenced as GLOBAL-REANALYSIS-PHY-001-031 for Global Reanalysis MultiModel Ensemble Product. Global ocean reanalyses are homogeneous three-dimensional gridded descriptions of the physical state of the ocean spanning several decades, produced with a numerical ocean model constrained with data assimilation of satellite and in situ observations. The SSS data used in this study were the daily data with a spatial resolution of $0.25^{\circ} \times 0.25^{\circ}$.

\subsubsection{Sea Surface Height Anomalies and Surface Geostrophic Velocity}

The sea surface height anomaly (SSHA) and sea surface geostrophic velocity data, calculated based on geostrophic relationships, were satellite altimeter data from the Ssalto/Duacs multisensor gridded delay-time altimetry product provided by Archiving, Validation and Interpretation of Satellite Oceanographic Data (AVISO) (https:/ / www. aviso.altimetry.fr/en/data/products/, (accessed on 1 April 2021)) and distributed by the Copernicus Marine and Environmental Monitoring Service. This product is processed from all satellite altimeter missions (Jason-3, Sentinel-3A, HY-2A, Saral/AltiKa, Cryosat-2, Jason-2, Jason-1, Topex/Poseidon, Environmental Satellite, Geosat Follow-On, European Remote Sensing satellites). The spatial resolution of the SSHA and geostrophic data is $0.25^{\circ} \times 0.25^{\circ}$ and the temporal resolution is $1 \mathrm{~d}$.

\subsubsection{Wind Vectors}

The wind vector datasets were the wind at $10 \mathrm{~m}$ above the sea surface from the CrossCalibrated Multi-Platform gridded surface vector winds provided by RSS. Cross-Calibrated Multi-Platform combines Version-7 RSS radiometer wind speeds, QuikSCAT and ASCAT scatterometer wind vectors, moored buoy wind data, and ERA-Interim model wind fields, and uses a variational analysis method to combine satellite observations and in situ wind measurements into gap-free wind fields, to produce four maps daily of $0.25^{\circ}$ gridded vector winds. Therefore, the temporal resolution of the wind field data used is $6 \mathrm{~h}$ and the spatial resolution is $0.25^{\circ} \times 0.25^{\circ}$.

\subsubsection{Precipitation}

The GPM mission is an international network of satellites based on the TRMM. The GPM carries the first satellite-borne Ku/Ka-band Dual-frequency Precipitation Radar and a multichannel GPM Microwave Imager to improve the ability to measure light rain and provide global observations of rain and snow. This study used the final product from the Integrated Multi-satellite Retrievals for GPM, which combines data from all passivemicrowave instruments in the GPM constellation and provides full coverage for latitudes $60^{\circ} \mathrm{S}-60^{\circ} \mathrm{N}$. The National Aeronautics and Space Administration's Precipitation Processing System publicly provided this product in March 2014 (https: / / pmm.nasa.gov/data-access / downloads/gpm, (accessed on 1 April 2021)). The precipitation data used were daily data with a spatial resolution of $0.1^{\circ} \times 0.1^{\circ}$. 


\subsubsection{Chlorophyll-a}

The ocean color merged datasets were obtained from GlobColour (http:/ / hermes. acri.fr/index.php?class=archive, (accessed on 1 April 2021)). The GlobColour dataset provides daily, weekly, and monthly chlorophyll concentrations with a spatial resolution of 4, 25, and $100 \mathrm{~km}$ from 1997 to the present, and the sensors include single-sensor and merged products from SeaWiFS, MERIS, MODIS, VIIRS NPP, OLCI-A, VIIRS JPSS-1, and OLCI-B. Merged data products are coalesced from multiple mission observations into a single data product with better spatial and temporal coverage than the individual missions. In this study, we used daily and weekly ocean color data with a spatial resolution of $25 \times 25 \mathrm{~km}$. In addition, chl-a datasets obtained from the three-dimensional global ocean forecast product produced by the Copernican Marine Environmental Monitoring Service Center (http:/ / marine.copernicus.eu / services-portfolio/access-to-products/, (accessed on 1 April 2021)) were used to show the sea surface two-dimensional fields of zooplankton. The two-dimensional fields of zooplankton data used were weekly data with a spatial resolution of $0.25^{\circ} \times 0.25^{\circ}$.

\subsubsection{Argo Profiles}

We extracted the Argo float profiles from the real-time quality-controlled Argo database of the China Argo Real-time Data Center (http: / / www.argo.org.cn, (accessed on 1 April 2021)). Argo is an array of 3887 active profiling floats, distributed almost uniformly across the global ocean, which provide temperature and salinity profiles from the surface to $2000 \mathrm{~m}$ depth. The array has approximately one float for every $3^{\circ}$ of latitude and longitude and provides accurate and comprehensive measurements of changes to ocean temperature and salinity, enabling systematic assessments of the physical state of the upper ocean. The Argo data are collected and made freely available by the International Argo Project and the national programs that contribute to it. In this study, four Argo floats were used (shown in Figure 1): float A1, 5901213 (on 21 November), float A2, 5902121 (on 1 December), float A3, 5900976 (on 22 November and 10 December), and float A4, 2900401 (on 23 November and 28 November).

\subsubsection{Mixed-Layer Depth}

The mixed-layer depth (MLD) dataset were from the three-dimensional global ocean reanalysis product produced by the Copernicus Marine and Environmental Monitoring Service Global Monitoring and Forecasting Centre (http:/ / marine.copernicus.eu/servicesportfolio/access-to-products/, (accessed on 1 April 2021)). The products assessed in this study are referenced as GLOBAL-REANALYSIS-PHY-001-031 for Global Reanalysis MultiModel Ensemble Product. Global ocean reanalyses are homogeneous three-dimensional gridded descriptions of the physical state of the ocean spanning several decades, produced with a numerical ocean model constrained with data assimilation of satellite and in situ observations. The MLD data used in this study were the daily data with a spatial resolution of $0.25^{\circ} \times 0.25^{\circ}$.

\subsection{Methods}

\subsubsection{Ekman Pumping}

The Ekman pumping velocity (EPV, unit: $\mathrm{m} \mathrm{s}^{-1}$ ) caused by Ekman pumping can be calculated as follows [1]:

$$
\mathrm{EPV}=\nabla \times(\tau / \rho \mathrm{f}),
$$

where $\nabla$ is a gradient operator (total differential in all directions of space), called the Hamilton operator, $\mathrm{f}$ is the Coriolis parameter, $\rho$ is the density of seawater (unit: $\mathrm{kg} \mathrm{m}^{-3}$ ), and $\tau$ is the wind stress vector (unit: $\mathrm{N}$ ),

$$
\tau=\rho_{\mathrm{a}} \mathrm{C}_{\mathrm{D}}\left|\mathbf{U}_{10}\right| \mathbf{U}_{10},
$$




$$
C_{D}=\left\{\begin{array}{cc}
\left(4-0.6\left|\mathbf{U}_{10}\right|\right) \times 10^{-3} & \text { for }\left|\mathbf{U}_{10}\right|<5 \mathrm{~m} / \mathrm{s} ; \\
\left(0.737+0.0525\left|\mathbf{U}_{10}\right|\right) \times 10^{-3} & \text { for } 5 \mathrm{~m} / \mathrm{s} \leq\left|\mathbf{U}_{10}\right|<25 \mathrm{~m} / \mathrm{s} \\
2.05 \times 10^{-3} & \text { for }\left|\mathbf{U}_{10}\right| \geq 25 \mathrm{~m} / \mathrm{s}
\end{array}\right.
$$

where $\rho_{\mathrm{a}}$ is the air density (unit: $\mathrm{kg} \mathrm{m}^{-3}$ ), $\mathrm{C}_{\mathrm{D}}$ is the drag coefficient $[25,26]$, and $\mathbf{U}_{10}$ is the $10 \mathrm{~m}$ wind vector (unit: $\mathrm{m} \mathrm{s}^{-1}$ ).

\subsubsection{Enthalpy Flux and Energy Budget}

The sensible heat flux $\mathrm{Q}_{\mathrm{S}}$ (unit: $\mathrm{W} \mathrm{m}^{-2}$ ) and latent heat flux $\mathrm{Q}_{\mathrm{L}}$ (unit: $\mathrm{W} \mathrm{m}^{-2}$ ) were calculated based on the bulk aerodynamic formula under the condition of tropical cycloneocean coupling [25,27] as follows:

$$
\begin{aligned}
& Q_{S}=C_{S} V\left(T_{s}-T_{a}\right) \rho_{a} C_{p a}, \\
& Q_{L}=C_{L} V\left(q_{s}-q_{a}\right) \rho_{a} L_{v a},
\end{aligned}
$$

where $C_{L}$ and $C_{S}$ are the latent and sensible heat exchange coefficients, respectively. $V$ is the wind speed derived from the modified Rankine vortex with $n$ defined as in Mei et al. [28] as follows:

$$
\left\{\begin{array}{c}
\mathrm{V}(\mathrm{r})=\mathrm{V}_{\max }\left(\frac{\mathrm{r}}{\mathrm{R}_{\max }}\right) \text { for } \mathrm{r}<\mathrm{R}_{\max } \\
\mathrm{V}(\mathrm{r})=\mathrm{V}_{\max }\left(\mathrm{r} / \mathrm{R}_{\max }\right)^{-\mathrm{n}} \text { for } \mathrm{r} \geq \mathrm{R}_{\max }
\end{array},\right.
$$

where $\mathrm{n}=0.6$. We used the model wind to calculate the heat flux because it is challenging for scatterometers to measure high and extreme winds [29], and the CCMP wind underestimated the wind speed by as much as 50\% [30]. Ts and Ta are the during-typhoon SST and near-surface air temperature (unit: ${ }^{\circ} \mathrm{C}$ ), and qs and qa are the surface and air specific humidity (unit: \%), respectively. Ta and qa are from the National Centers for Environmental Prediction (NCEP) reanalysis dataset (http:/ / apdrc.soest.hawaii.edu/erddap/search/ index.html?page $=1 \&$ itemsPerPage $=1000 \&$ searchFor $=$ NCEP+-ofes+-godas, (accessed on 1 April 2021)). $C_{p a}$ is the specific heat of air at constant pressure, $L_{v a}$ is the latent heat of vaporization, $\rho_{\mathrm{a}}$ is the air density (unit: $\mathrm{kg} \mathrm{m}^{-3}$ ), and $\mathrm{q}_{\mathrm{s}}$ is the saturated specific humidity (unit: \%). The frictional heat $\mathrm{D}$ (unit: $\mathrm{W} \mathrm{m}^{-2}$ ) generated by the friction between the typhoon and ocean is calculated as follows:

$$
\mathrm{D}=\rho_{\mathrm{a}} \mathrm{C}_{\mathrm{D}} \mathrm{V}^{3}
$$

A typhoon is regarded as a Carnot heat engine, and the heat conversion

$$
\text { efficiency }=(\mathrm{SST}-\mathrm{CTT}) / \mathrm{SST}
$$

where CTT is the cloud top temperature (unit: ${ }^{\circ} \mathrm{C}$ ). The ocean energy input into the typhoon $\mathrm{W}$ (unit: $\mathrm{W} \mathrm{m}^{-2}$ ) is:

$$
\mathrm{W}=\left(\mathrm{Q}_{\mathrm{S}}+\mathrm{Q}_{\mathrm{L}}+\mathrm{D}\right) \times \text { efficiency }
$$

The net energy input of the ocean to typhoon $\mathrm{N}$ (unit: $\mathrm{W} \mathrm{m}^{-2}$ ) is:

$$
\mathrm{N}=\mathrm{W}-\mathrm{D}
$$

In accordance with previous studies [10,27], we did not consider the radiation term when calculating the change in typhoon energy, although the radiation term is an important variable in the energy budget.

\subsubsection{Method to Evaluate Ocean Responses}

The grid-based maximum response (GMR) method proposed by Li et al. [31] is a new method to accurately evaluate the SST response to a typhoon by using the asynchronous SST fields. In the first step, the initial forcing time (Ti) and the terminal forcing time (Tt) of typhoon are recorded, and the SST response period is defined as the time from the start time $(\mathrm{Ti}-2)$ to the end time $(\mathrm{Tt}+5)$ in each grid. In the second step, the average SST 
of two days $(\mathrm{Ti}-2)$ and one day $(\mathrm{Ti}-1)$ before the initial forcing time are selected as the background SST, and the minimum SST between the initial forcing time (Ti) and the terminal time $(\mathrm{Tt}+5)$ is selected as the responding SST. The SST cooling in each grid is evaluated by the difference between the responding SST and background SST. In the last step, the SST cooling response in each grid is displayed in the map as GMR SST cooling results. Schematic illustration of the GMR method can be found in Figure 2 in Li et al. [30]. Using daily data from satellite remote sensing, this method can accurately calculate the maximum amplitude of SST cooling and the location of SST cooling centers.
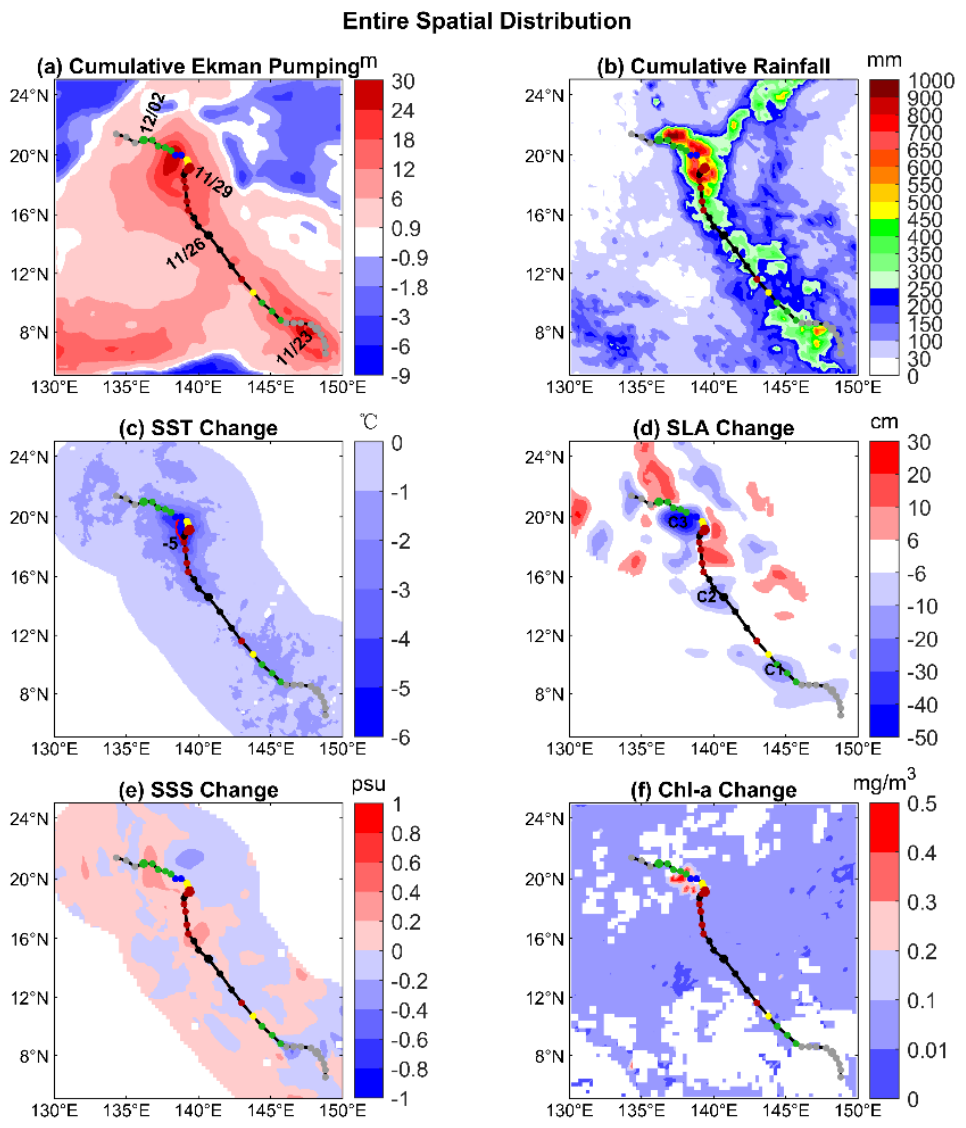

Figure 2. The entire spatial distribution of (a) cumulative Ekman pumping, (b) cumulative rainfall, (c) SST change (the red solid line shows the $5{ }^{\circ} \mathrm{C}$ contour), (d) SSHA change, (e) SSS change, and (f) chl-a change during the lifespans of Nida from 22 November 2009 to 3 December 2009. Ekman pumping and rainfall are the cumulative value during typhoon lifespans. Other graphs (such as SST change) are the maximum ocean responses caused by typhoon in its lifespans calculated by GMR method proposed by Li et al. [31].

\subsubsection{Large-Scale Eddy Transport}

Eddies were detected with the SSHA data [32]. Specifically, if there was a series of closed contours in the SSHA field, when the value of the outermost closed contour was greater than $6 \mathrm{~cm}$, the region was defined as a warm eddy; when the outermost closed contour was less than $-6 \mathrm{~cm}$, the region was defined as a cold eddy (CE) [33,34].

A CE in NPWO would affect large-scale transport in several ways [33]. Previous studies stressed the negative transport by CE that is well known when CE dissipated in ocean interior [35]. However, if CE propagates westward to west boundary, it may have a positive transport for NPWO. This new mechanism was discovered recently [36]. In this study, we only stressed the transport by positive feedback mechanism, since the west propagating CE was very close to west boundary other than ocean interior. Zhang et al. [36] 
evaluated the eddy effect on Kuroshio transport based on the well-known turbulent Sverdrup balance as follows:

$$
\mathrm{S}_{\mathrm{v}}=\frac{1}{\beta} \int\left|\mathbf{u}_{\mathbf{w}}\right| \Delta \mathrm{Qdy},
$$

where $\beta$ is the beta effect, $\mathbf{u}_{\mathbf{w}}$ denotes the eddies' westward propagation, and $\Delta \mathrm{Q}$ denotes the potential vorticity anomaly. The formula is general for middle latitude ocean dynamics. Besides, the Typhoon Nida passing region is just within where Zhang et al. [36] studied (the Northwest Pacific and the Kuroshio area). According to the eddy structure model proposed by Wang et al., [37], a surface eddy consists of three parts and potential vorticity anomaly $\Delta \mathrm{Q}$ is:

$$
\Delta \mathrm{Q}=\left(\frac{\mathrm{f}+\zeta}{\mathrm{H} 1+\mathrm{h} 1+\mathrm{h} 2}-\frac{\mathrm{f}}{\mathrm{H} 1}\right) \times(\mathrm{H} 1+\mathrm{h} 1+\mathrm{h} 2),
$$

where $\mathrm{h} 1$ is the upper surface, $\mathrm{h} 2$ is the lower surface, $\mathrm{H} 1$ is the eddy body of height, $\zeta$ is the relative vorticity.

\section{Results}

\subsection{Oceanic Responses in the Entire Area}

Super typhoon Nida induced strong winds and severe rainfall around the track during its lifespan. Figure 2a shows the cumulative Ekman pumping caused by Nida during its passage. During the sudden turning dates (23 November and 30 November), Nida induced strong accumulation ( $>24 \mathrm{~m}$ ) of Ekman pumping, which was in contrast to a very weak wind field and local Ekman pumping $(<6 \mathrm{~m})$ before Nida entered. During the passage of typhoon Nida, strong winds prevailed, with the upwelling velocity ranging from 0.5 to $4 \times 10^{-4} \mathrm{~m} \mathrm{~s}^{-1}$ (Figure S1). Figure $2 \mathrm{~b}$ shows the cumulative rainfall during the passage of the typhoon. The rainfall was mainly concentrated in the ST stage of the typhoon, during which the accumulated rainfall exceeded $1000 \mathrm{~mm}$, and the rainfall induced by the typhoon was mainly located on the right-hand side of the typhoon track (for the daily evolution, see Figure S2).

Figure 2c shows the SST response field calculated using the GMR method. Before Nida entered, the SST in the study area was dominated by warm temperatures higher than $28^{\circ} \mathrm{C}$ (Figure S3 in SM). In the SL stage, the cold wake was obviously lagging behind the typhoon center and the SST cooling showed an obvious right-hand bias. In contrast, the maximum SST cooling overlapped the typhoon center and was located on the left-hand side of the track in the ST stage. From Figure 2c, the SST cooling mainly occurred in the ST stage of the typhoon and almost all of the strong cooling area greater than $5{ }^{\circ} \mathrm{C}$ was located on the left-hand side of the typhoon track (with the maximum SST decrease of $6.68{ }^{\circ} \mathrm{C}$ about $80 \mathrm{~km}$ to the left of the typhoon track). This strong "left-bias" SST cooling induced by Nida is unusual, since most previous studies show a "right-bias" of the SST cooling owing to better wind-current resonance [1,38] and sub-mesoscale recirculation cells [39] on the right-hand side in the Northern Hemisphere. Therefore, the strong "left-bias" SST cooling induced by Nida should be paid particular attention and stressed in detail in Section 3.2.

The SSHA response to Nida calculated using the GMR method is shown in Figure 2d. The results suggest three main centers along the typhoon track where the SSHAs decreased, marked as C1, C2, and C3, respectively. C3 in the ST stage was strongest and the maximum SSHA reached $-60 \mathrm{~cm}$. This was because of the strong upwelling in the ST stage. In contrast, $\mathrm{C} 1$ and $\mathrm{C} 2$ in the SL stage were relatively weak. The evolution of the SSHA fields (Figure S4) show that the SSHAs in the study area were mostly higher than $-20 \mathrm{~cm}$ before the arrival of Nida, and then gradually decreased during the typhoon's passage.

Figure 2e shows the distribution of the SSS response field calculated using the GMR method. The results show that the area where the SSS increased by 0.6 psu corresponded to the strong Ekman pumping area, and that the area where the SSS decreased by $0.6 \mathrm{psu}$ corresponded to the heavy rainfall area (for the daily evolution, see Figure S5). In summary, the change in SSS was mainly determined by a mechanism of competition between the asymmetric typhoon precipitation and asymmetric Ekman pumping. 
Figure $2 \mathrm{f}$ shows the chl- $a$ difference before and after Nida, indicating that the chl- $a$ concentration increased by $0.5 \mathrm{mg} \mathrm{m}^{-3}$, which was about five times that before the passage of Nida, and the chl- $a$ bloom lasted for weeks after Nida passed. Compared with the ST stage, the chl- $a$ concentration in the SL stage barely changed. Furthermore, the region with the highest chl- $a$ increase (Figure S6c,g) corresponded to the region with the strongest SST cooling (Figure S3i,j) and SSHA decrease (Figure S4i,j).

Recent case studies have found that typhoons can modulate the large-scale flow, e.g., the Kuroshio Current, via cold eddy intensification $[35,36,40]$. In this study, we estimated the potential mass transport induced by the strong cold eddy caused by typhoon Nida in the sudden-turning stage. The height of the cold eddy body $\mathrm{H} 1$ was about $300 \mathrm{~m}$ from Argo measurements; the upper surface h1 was about $-0.3 \mathrm{~m}$ from sea surface height anomaly field; and the lower surface h2 was about 200 times that of the eddy amplitude h1 according to Wang et al., [37]. These are typical values for the Northwest Pacific, which were obtained as a composite structure from Argo and other observations [41]. The westward speed of the eddy was about $0.27 \mathrm{~m} \mathrm{~s}^{-1}$. Based on Equations (11) and (12), the strong cold eddy induced by Nida contributed about $0.25 \mathrm{~Sv}$ of mass transport to the large-scale mass transport (i.e., Kuroshio), which is about 0.6 times the total mass transport (0.4 Sv) in the South China Sea [35] and 0.4-0.6\% of the total contribution to the mass transport ( $40-60 \mathrm{~Sv})$ by the Kuroshio. The temporal evolutions of the mean SSHA of the eddy and the transport induced by it are shown in Figure S7. Although the potential Kuroshio Current strengthening by of a single typhoon and eddy is not significant, there are 20-30 typhoons per year in this region, the integration of all typhoons and eddies may play a nonnegligible role for the Kuroshio Current (Zhang et al., [36] did this with composite analysis of typhoons between 1993 and 2014). The story of the relationship between typhoon and Kuroshio is a part of climate response of typhoon-ocean interaction, which is not very clear yet, so we simply add this part as an example or comparison for further studies.

\subsection{Comparison of Oceanic Responses in Two Category 5 Stages}

To summarize the regularity of the typhoon-ocean interaction under different typhoon motions, we quantitatively compared the ocean responses in the two Category 5 typhoon stages in detail. Two representative sections were selected for the two stages, as marked in Figure 1.

\subsubsection{Direct Response during the Typhoon's Passage}

Figure 3 shows the temporal evolution of the cross-track SSW, Ekman pumping, rainfall, SST, SSHAs, and SSS at section 1 during 23 November to 1 December 2009. The SSW field and Ekman pumping intensity at section 1 strengthened on 25 November and then weakened on 26 November. Meanwhile, the maximum SSW (14.2 $\left.\mathrm{m} \mathrm{s}^{-1}\right)$ and EPV $\left(1.03 \times 10^{-4} \mathrm{~m} \mathrm{~s}^{-1}\right)$ on the right-hand side were obviously stronger than on the left-hand side of the typhoon track in the SL stage. Figure 3c shows that the evolution of the rainfall corresponded to Ekman pumping in the time series, but the rainfall appeared with a relatively leftward bias. The SST began to decrease on 24 November and appeared with a rightward bias. Figure 3e shows that the maximum SST cooling center $\left(1^{\circ} \mathrm{C}\right)$ caused by Nida was located at about $100 \mathrm{~km}$ on the right-hand side of the typhoon path. Figure $3 \mathrm{f}, \mathrm{g}$ show that the SSHA decreased by about $3 \mathrm{~cm}$ from 24 November to 1 December. The SSS at section 1 changed slightly within the range from -0.02 psu to 0.02 psu (Figure $3 h, i$ ). In summary, at section 1, although the Ekman pumping velocity and rainfall were something notable due to the strongest intensity of $155 \mathrm{kts}$, the upper ocean responses (SST, SSHA, and SSS) were quite weak owing to the straight-line track and fast speed. 

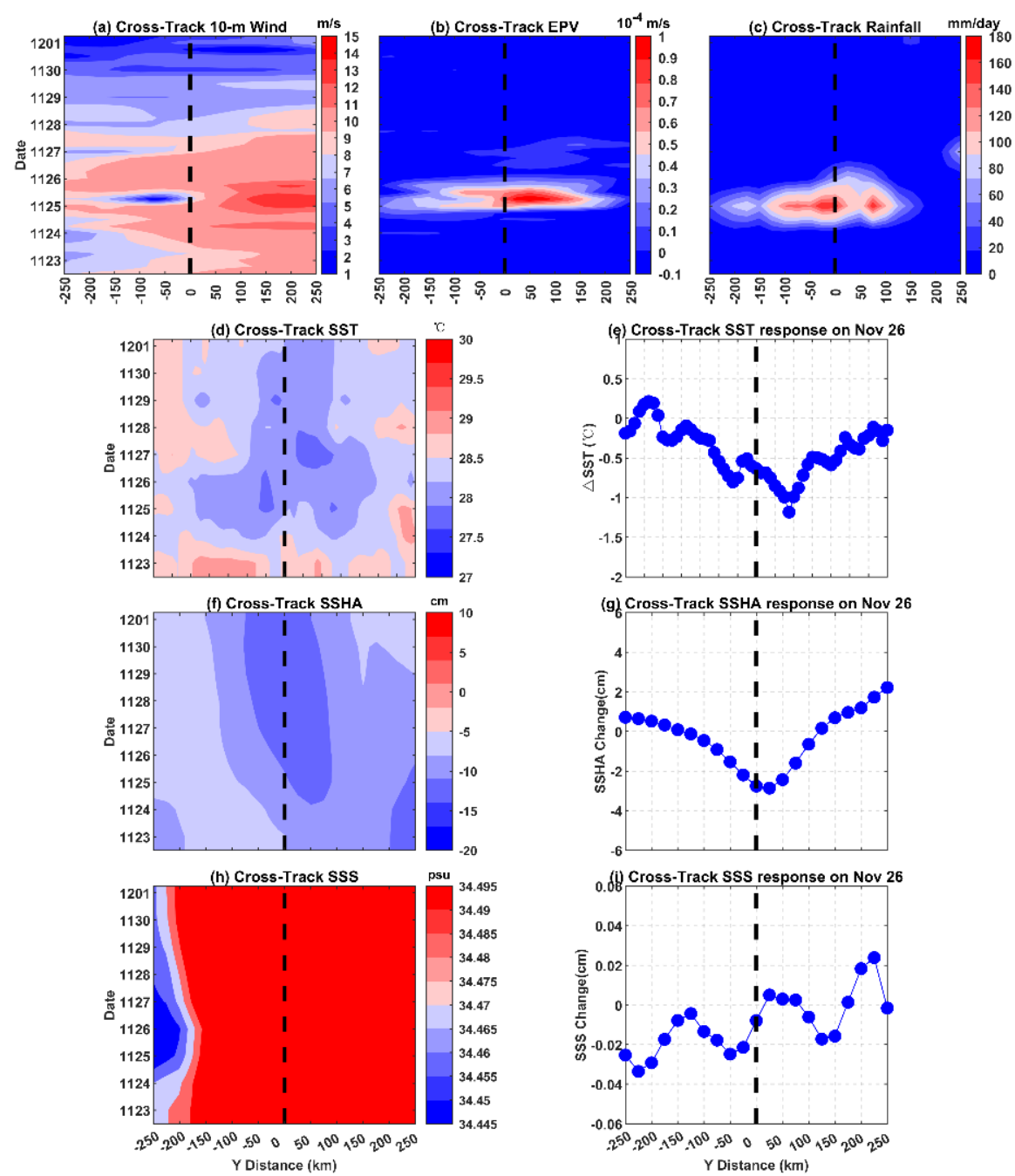

Figure 3. Temporal evolution of cross-track (a) SSW (shaded, $\mathrm{m} \mathrm{s}^{-1}$ ), (b) cumulative Ekman pumping (shaded, $\mathrm{m}$ ), and (c) cumulative rainfall (shaded, $\mathrm{mm}$ ) at location 1 during the passage of typhoon Nida (23 November-1 December 2009). (d,e) Temporal evolution of cross-track SST (shaded, ${ }^{\circ} \mathrm{C}$ ) and the cross-track SST response on 26 November. $(\mathbf{f}, \mathbf{g})$ Temporal evolution of cross-track SSHA (shaded, $\mathrm{cm})$ and the cross-track SSHA response on 26 November. $(\mathbf{h}, \mathbf{i})$ Temporal evolution of cross-track SSS (shaded, psu) and the cross-track SSS response on 26 November.

Figure 4 shows the temporal evolution of the cross-track SSW, Ekman pumping, rainfall, SST, SSHAs, and SSS at section 2 during 26 November to 4 December 2009. The SSW and Ekman pumping strengthened from 27 November to 30 November. It was exactly opposite to section 1, in that the maximum SSW $\left(23.2 \mathrm{~m} \mathrm{~s}^{-1}\right)$ and EPV $\left(3.61 \times 10^{-4} \mathrm{~m} \mathrm{~s}^{-1}\right)$ on the left-hand side were obviously stronger than on the right-hand side SSW $\left(15.9 \mathrm{~m} \mathrm{~s}^{-1}\right)$ and EPV $\left(2.07 \times 10^{-4} \mathrm{~m} \mathrm{~s}^{-1}\right)$ at section 2 (Figure S8). Figure 4c shows that the typhooninduced rainfall was concentrated from 27 to 30 November and the strongest rainfall exceeded $320 \mathrm{~mm} \mathrm{~d}^{-1}$. The cross-track SST at section 2 began to decrease on 27 November and appeared with an obvious leftward bias (Figure $4 \mathrm{~d}$ ). The maximum SST cooling center $\left(>6^{\circ} \mathrm{C}\right.$ ) was located $80 \mathrm{~km}$ to the left of the typhoon track, and was relatively larger than the SST cooling center $\left(5.42^{\circ} \mathrm{C}\right)$ on the right-hand side (Figure $\left.4 \mathrm{e}\right)$. Figure $4 \mathrm{f}, \mathrm{g}$ show that the SSHAs decreased from 26 November to 4 December and the maximum SSHA decrease exceeded $30 \mathrm{~cm}$ on the left-hand side of track. 


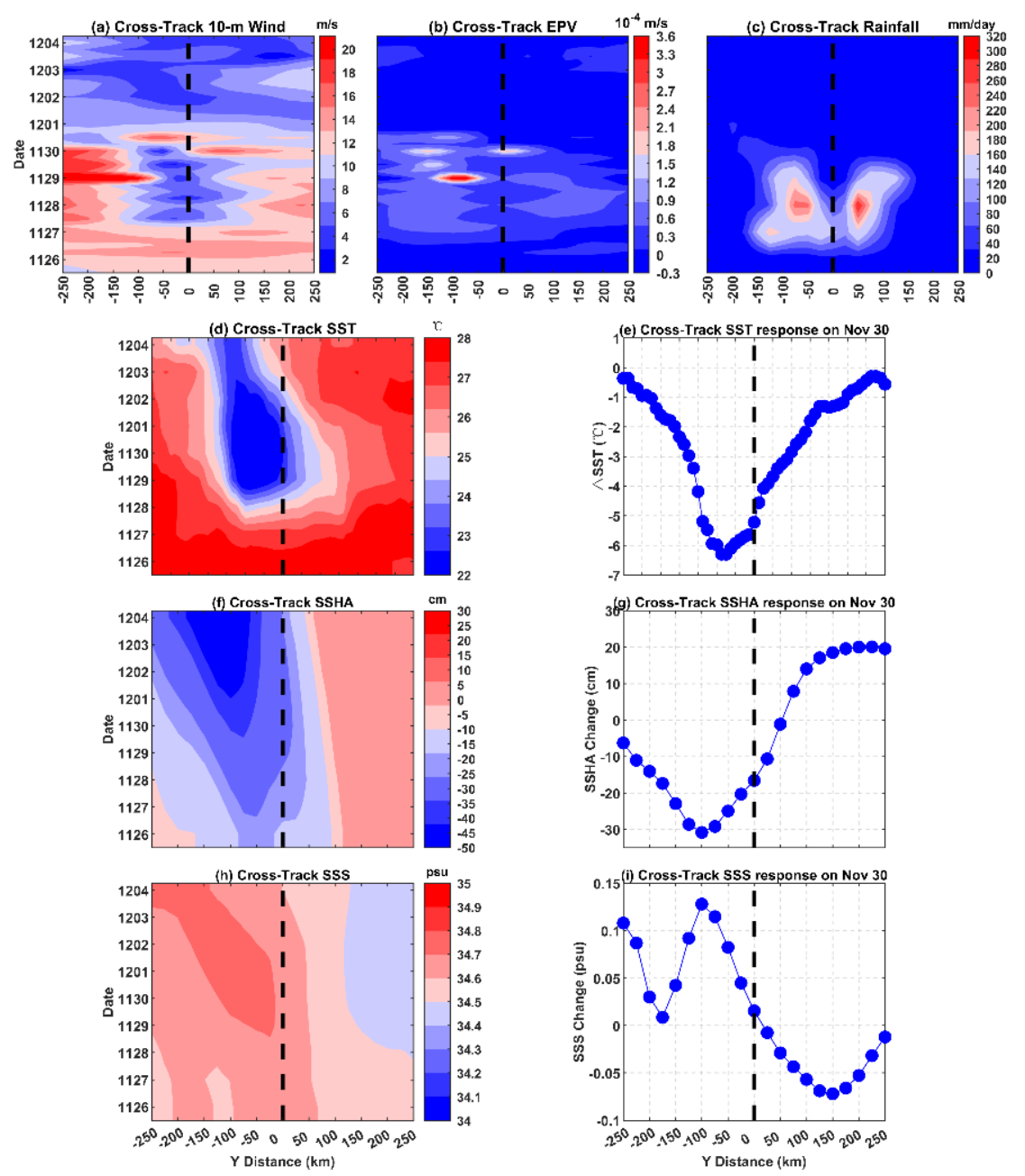

Figure 4. Temporal evolution of cross-track (a) SSW (shaded, $\mathrm{m} \mathrm{s}^{-1}$ ), (b) cumulative Ekman pumping (shaded, $\mathrm{m}$ ), and (c) cumulative rainfall (shaded, $\mathrm{mm}$ ) at location 2 during the passage of typhoon Nida (30 November-4 December 2009). (d,e) Temporal evolution of cross-track SST (shaded, ${ }^{\circ} \mathrm{C}$ ) and the cross-track SST response on 30 November. $(\mathbf{f}, \mathbf{g})$ Temporal evolution of cross-track SSHAs (shaded, $\mathrm{cm})$ and the cross-track SSHA response on 30 November. $(\mathbf{h}, \mathbf{i})$ Temporal evolution of cross-track SSS (shaded, psu) and the cross-track SSS response on 30 November.

Therefore, the left-bias SST cooling phenomenon during the ST stage could have resulted for the following reasons. First, the asymmetrical typhoon wind field was stronger on the left-hand side (Figure 4a,b) and the cyclonic left-turning made EPV stronger than on the right-hand side. Secondly, according to previous research [18], the forcing time of typhoon Nida was longer on the left-hand side due to the sudden left-turning of the track, both resulting in stronger cumulative Ekman pumping, as shown in Figure 1. The stronger cumulative Ekman Pumping consequently generated a cyclonic cold eddy, which can significantly enhance the SST cooling induced by the typhoon $[3,42]$. In summary, both the typhoon wind and the ocean condition were favorable to the left-bias SST cooling (Figure S8).

The SSS increased on the left-hand side of the track but decreased on the right-hand side, with the SSS response ranging from -0.05 to $0.05 \mathrm{psu}$ at section 2 (Figure $4 \mathrm{~h}$ ). The asymmetric SSS response was influenced by asymmetric rainfall (Figure 4c). It can be clearly seen that the cross-track evolutions of SST (Figure 4d), SSHAs (Figure 4f) and SSS (Figure $4 \mathrm{~h}$ ) were highly consistent in the time series, due to the typhoon-induced Ekman pumping (Figure $4 \mathrm{~b}$ ). In summary, at section 2, both the ocean responses and rainfall were notable because of the long-term forcing of the strong EPV by cyclonic sudden-turning of this strong typhoon. 


\subsubsection{Long-Term Memory Response after the Typhoon's Passage}

In addition to the direct response of the upper ocean, we studied the long-term impact of typhoon Nida on the marine environment by comparing the marine environment two weeks after the typhoon's passage. In the SL stage, the long-memory ocean responses one week and two weeks after Nida passed showed that the SSHAs, SST, and chl-a distribution indicated that the ocean responses recovered rapidly within a week (Figure 5).

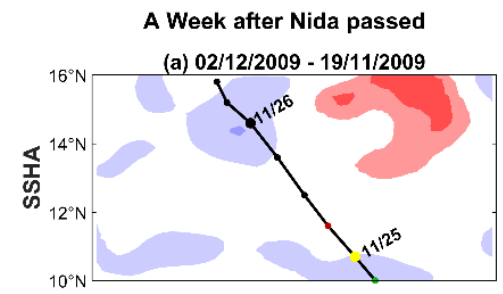

Two Weeks after Nida passed (b) 09/12/200 9- 19/11/2009

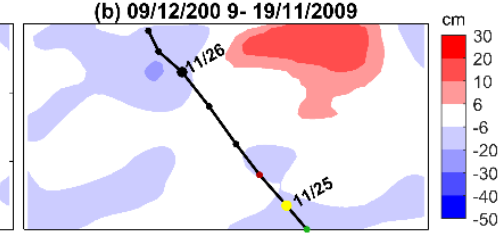

(c) $02 / 12 / 2009-19 / 11 / 2009$

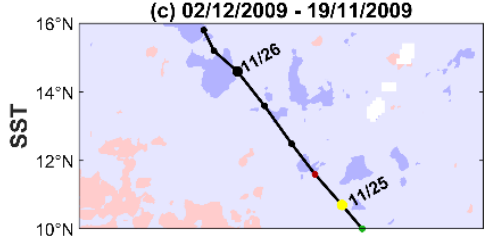

(d) $09 / 12 / 2009-19 / 11 / 2009$

(e) 25/11 02/12/2009 - 17 24/11/2009
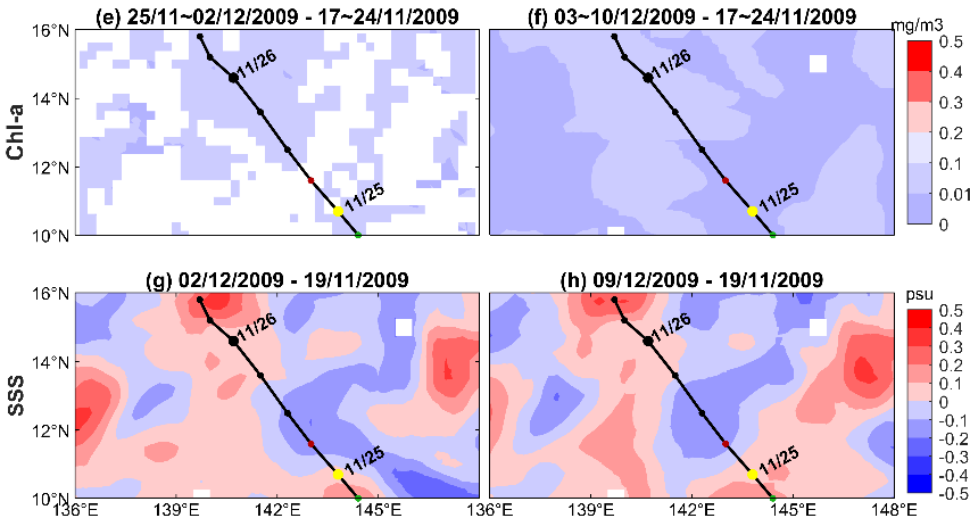

Figure 5. The straight-line stage. (a,b) The SSHA fields (shaded, $\mathrm{cm}$ ) on 9 and 15 December 2009, indicating one week and two weeks after the passage of Nida, respectively. (c,d) The SST responses (shaded, $\mathrm{cm}$ ) on 9 and 15 December 2009. (e,f) The chl-a responses (shaded, $\mathrm{cm}$ ) several weeks after the passage of typhoon Nida. (g,h) The SSS responses (shaded, $\mathrm{cm}$ ) on 9 and 15 December 2009.

In contrast, Figure 6 shows the long-memory ocean response one week and two weeks after Nida passed in the ST stage. The SSHA response (Figure 6a,b) indicates that the strong cold eddy with an SSHA decrease of $60 \mathrm{~cm}$ generated by Nida in the ST stage existed and strengthened for several weeks. Such an SSHA response delay after the passage of typhoon has also been noted in previous studies [43,44], and confirmed with Argo and SST data due to sustained upwelling [21,40]. However, the exact delay date might be uncertain [44], as the temporal resolution of the grid can be higher than two weeks $[45,46]$. Figure $6 c, d$ show that Nida induced a maximum SST cooling exceeding $6{ }^{\circ} \mathrm{C}$, which lasted more than two weeks (Figure 6a,b). Meanwhile, for several weeks after the passage of Nida, the cold eddy caused a long-lasting chl-a bloom exceeding $0.6 \mathrm{mg} \mathrm{m}^{-3}$ and an SSS increase of $0.6 \mathrm{psu}$, as shown in Figure 6e,f and Figure 6g,h, respectively. This played an important role in the upper marine ecological environment and marine transport of salinity, nutrients, and chlorophyll. As is well known, in the tropical oceans, limited nutrient concentrations in the upper ocean are not conducive to enhancing primary productivity [47-49]. Typhoon Nida induced the transport of richer nutrients from the subsurface to the surface layer, and together with the "presumed" sufficient sunlight and photosynthesis after the passing of the typhoon, there was a marked increase in the surface chl-a concentration, especially on 
the left-hand side of the typhoon track (five times that before the typhoon's passage). Lin and Oey [50] also showed that the typhoon's left-side rainfall can induce left-side blooming, but in the case of Nida the left-side blooming was dominated by the strong upwelling within the strong cold eddy. Therefore, typhoon Nida not only directly affected the upperocean environment during its passage, but also induced long-term non-negligible ocean responses by forcing the formation of the cold eddy.
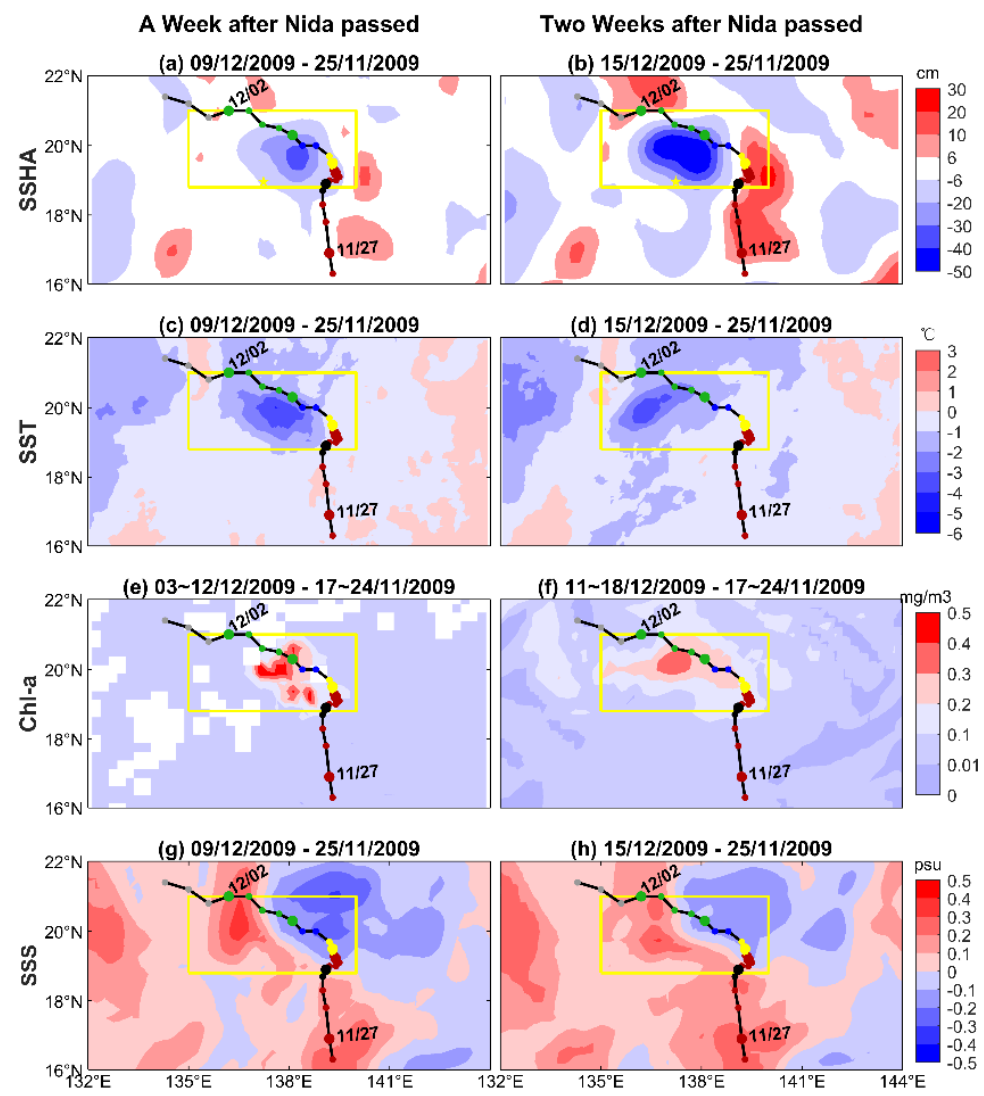

Figure 6. The sudden-turning stage. (a,b) The SSHA fields (shaded, cm) on 9 and 15 December 2009, indicating one week and two weeks after the passage of Nida, respectively. (c,d) The SST responses (shaded, cm) on 9 and 15 December 2009. (e,f) The chl- $a$ and zooplankton responses (shaded, cm) several weeks after the passage of typhoon Nida. (g,h) The SSS responses (shaded, $\mathrm{cm}$ ) on 9 and 15 December 2009. The yellow rectangle and yellow star indicate the cold eddy area and the location of Argo float 2900401, respectively.

Furthermore, we quantified the average ocean responses along the typhoon track in the two Category 5 stages (Table 1). The high-latitude MLD in the ST stage was slightly deeper than the low-latitude MLD in the SL stage. The average intensity of Nida for both stages was about $120 \mathrm{kts}$. However, the turning angle and speed of Nida were quite different in the two stages. In the ST stage, the turning angle and speed were $62.48^{\circ}$ and $0.94 \mathrm{~m} \mathrm{~s}^{-1}$, respectively, which were four times and one-quarter of the turning angle of $15.68^{\circ}$ and speed of $4.39 \mathrm{~m} \mathrm{~s}^{-1}$ in the SL stage. Under the conditions of a similar ocean environment and typhoon intensity, the SST response, SSHA response and chl- $a$ response in the ST stage were $-4.15{ }^{\circ} \mathrm{C},-10.29 \mathrm{~cm}$, and $0.12 \mathrm{mg} \mathrm{m}^{-3}$, which were three times, two times, and four times those in the SL stage, respectively. In summary, owing to the difference in turning angle and speed, the upper ocean responses during the ST stage were about three times more than those in the SL stage. 
Table 1. Quantitative impact factors and biophysical responses in the two Category 5 stages.

\begin{tabular}{ccc}
\hline & SL Stage & ST Stage \\
\hline MLD $(\mathrm{m})$ & 33.41 & $62.08(\uparrow)$ \\
MSW speed $(\mathrm{kts})$ & 120.77 & $120.00(=)$ \\
SSW speed $\left(\mathrm{m} \mathrm{s}^{-1}\right)$ & 10.21 & $13.94(\uparrow)$ \\
Turning angle $\left({ }^{\circ}\right)$ & 15.68 & $62.48(\uparrow)$ \\
Translation speed $\left(\mathrm{m} \mathrm{s}^{-1}\right)$ & 4.39 & $0.94(\downarrow)$ \\
Rainfall $\left(\mathrm{mm} \mathrm{d}^{-1}\right)$ & 264.58 & $601.02(\uparrow)$ \\
SST response $\left({ }^{\circ} \mathrm{C}\right)$ & -1.44 & $-4.15(\uparrow)$ \\
SSHA response $(\mathrm{cm})$ & -5.00 & $-10.29(\uparrow)$ \\
SSS response $(\mathrm{psu})$ & 0.06 & $0.00(\downarrow)$ \\
Chl-a response $\left(\mathrm{mg} \mathrm{m}^{-3}\right)$ & 0.03 & $0.12(\uparrow)$
\end{tabular}

Note. The MLD, SSW, rainfall, SST, SSHA, SSS and chl- $a$ were averaged along the typhoon in the two stages: SL stage was from 24 November 06:00 to 27 November 12:00; ST stage was from 27 November 18:00 to 30 November 12:00. The signals up, down or equal mean the variables in the SL stage higher than, lower than or equal to the ST stage.

\subsubsection{Subsurface Response}

To investigate the subsurface response, we analyzed vertical profiles of temperature and salinity measured by Argo floats before and after typhoon Nida (Figure 7). Typhoon Nida affected floats 5901213 and 5902121 on 24 November. At this time, Nida moved fast and its intensity was weak, with an MSW speed of 65 kts. As shown in Figure 7a, the thickness of the mixed layer showed no obvious change after Nida passed. Nida affected float 5900976 from 26 to 27 November after it reached the maximum intensity, increasing the MLD by $35 \mathrm{~m}$ (Figure 7c). Float 2900401 was located at the sudden-turning track and was affected by Nida from 28 November to 1 December. During this stage, the MLD increased by $50 \mathrm{~m}$ (Figure 7e). At all three locations, the subsurface temperature responses showed a three-layer (decreasing-increasing-decreasing) vertical structure (Figure 7b,d,f). In addition, Figure $7 \mathrm{~g}, \mathrm{~h}$ show the temporal evolution of temperature and salinity profiles measured by Argo float 2900401. First, Nida induced strong vertical mixing that not only cooled the surface but also heated the subsurface, which is the so-called 'heat pump' effect of the typhoon [10,51]. In the following, the cyclonic stress of the typhoon caused a strong uplift of the ocean thermocline, which acted as a 'cold suction' to the upper ocean $[52,53]$. Therefore, the upper-ocean response to typhoon Nida consisted of two consequential processes: strong vertical mixing and long-lasting upwelling. Consistent with the research on 14 typhoons presented by Hsu and Ho [54] through Glider data with higher temporal resolution, the two main effects occurring in the temperature profile of the typhoon response are cold suction due to upwelling and heat pumping owing to vertical mixing. The subsurface warming induced by Nida were showed not only at Category 5 (Figure 7d,f: floats 5900976 and 2900401), but also Category 1 (Figure 7b: floats 5901213 and 5902121), which is consistent with the observation in Hsu and Ho (2019): "significant subsurface warming for typhoons belonging to all categories". In addition, according the types of heat pump in Hsu and Ho [54], the subsurface temperature responses induced by Nida belonged to the second type, which was characterized by surface cooling and subsurface warming with additional layers of cooling and warming in the thermocline. The shift of the T, S profiles measured by the Argo floats may also have played a minor role, since only a minor part shifted within the eddy and the major part propagated with the eddy. 

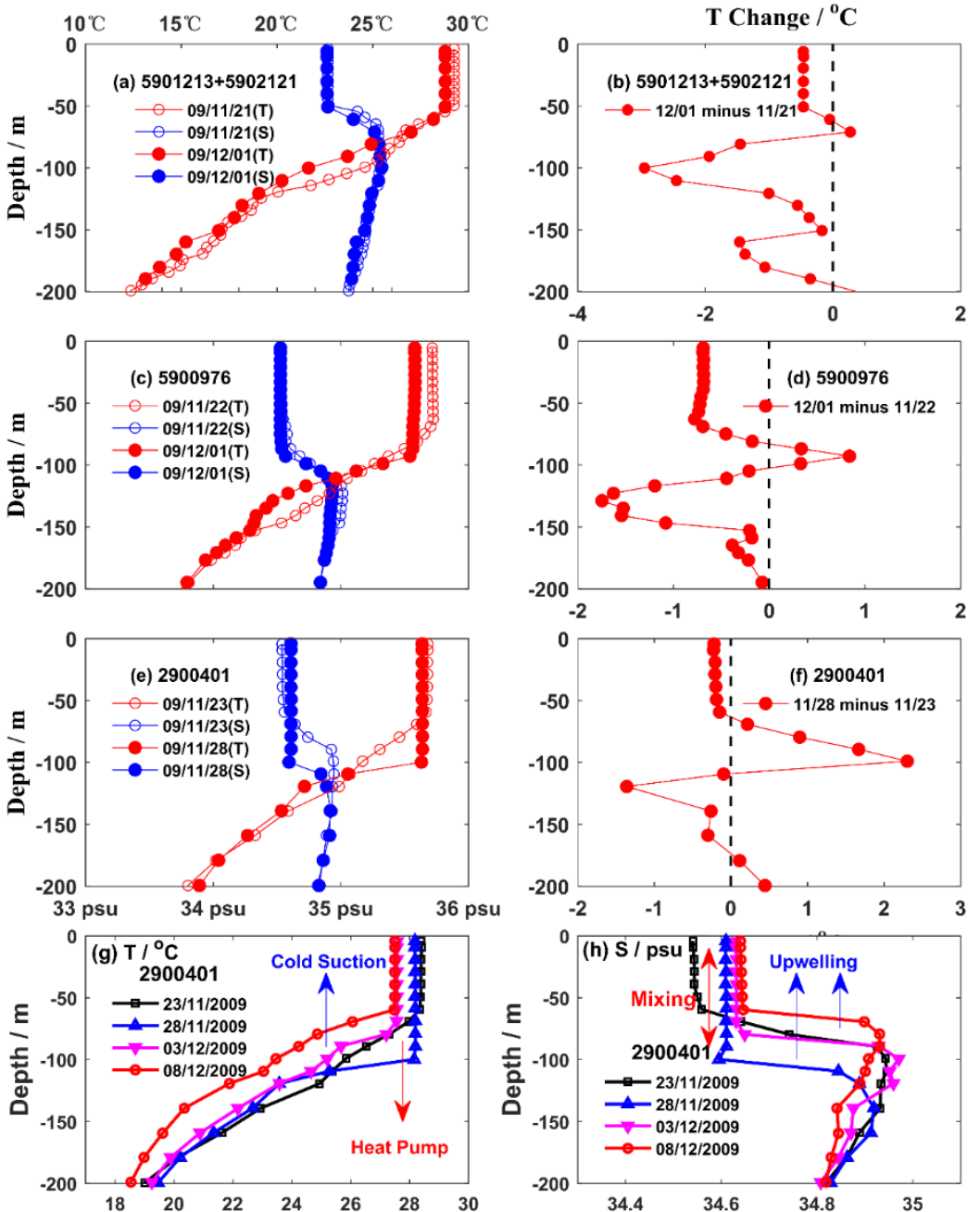

Figure 7. Temperature and salinity profiles, and temperature differences between the post-storm and pre-storm, measured by Argo floats 5901213 and $5902121(\mathbf{a}, \mathbf{b}), 5900976(\mathbf{c}, \mathbf{d})$, and $2900401(\mathbf{e}, \mathbf{f})$. (g,h) Temporal evolution of temperature and salinity profiles measured by Argo float 2900401 before and after Nida.

\subsection{Upper-Ocean Feedback to Typhoon Nida}

To investigate the negative feedback of the cold wake on the typhoon intensity, Figure 8 shows the evolution of Nida's inner-core cold wake and inner-core enthalpy flux (sensible heat flux and latent heat flux) in the two Category 5 stages. In accordance with previous studies $[14,55]$, we defined the typhoon inner core as the distance within a radius of $100 \mathrm{~km}$ from the typhoon center, indicated by the black solid circle in Figure 8 . When Nida moved in a straight line in the SL stage, the cold wake induced by Nida lagged far behind the inner-core area because of Nida's fast speed (Figure 8a,b). Figure 8e,f indicate that the air-sea enthalpy flux supplied from the ocean to Nida was considerable, especially on 26 November, with the maximum enthalpy flux exceeding $1000 \mathrm{~W} \mathrm{~m}^{-2}$. Therefore, Nida intensified rapidly in the SL stage. However, in the ST stage, the inner-core SST cooling was notable because the local cold wake no longer lagged behind the typhoon center, but completely overlapped the typhoon's inner core due to the sudden-turning track of the typhoon (Figure 8c,d). The strong inner-core SST cooling resulted in a sharp decrease of the enthalpy fluxes at the sea-air interface and the inner-core enthalpy flux decreased sharply from $681.9 \mathrm{~W} \mathrm{~m}^{-2}$ on 26 November to $-101.2 \mathrm{~W} \mathrm{~m}^{-2}$ on 30 November, especially on the left-hand side of the track (Figure $8 \mathrm{~g}, \mathrm{~h}$ ). Furthermore, the sharp decrease of the inner-core enthalpy fluxes caused the energy supply from the ocean to the typhoon to cease, rapidly weakening the intensity of typhoon Nida from Category 5 to Category 2. 

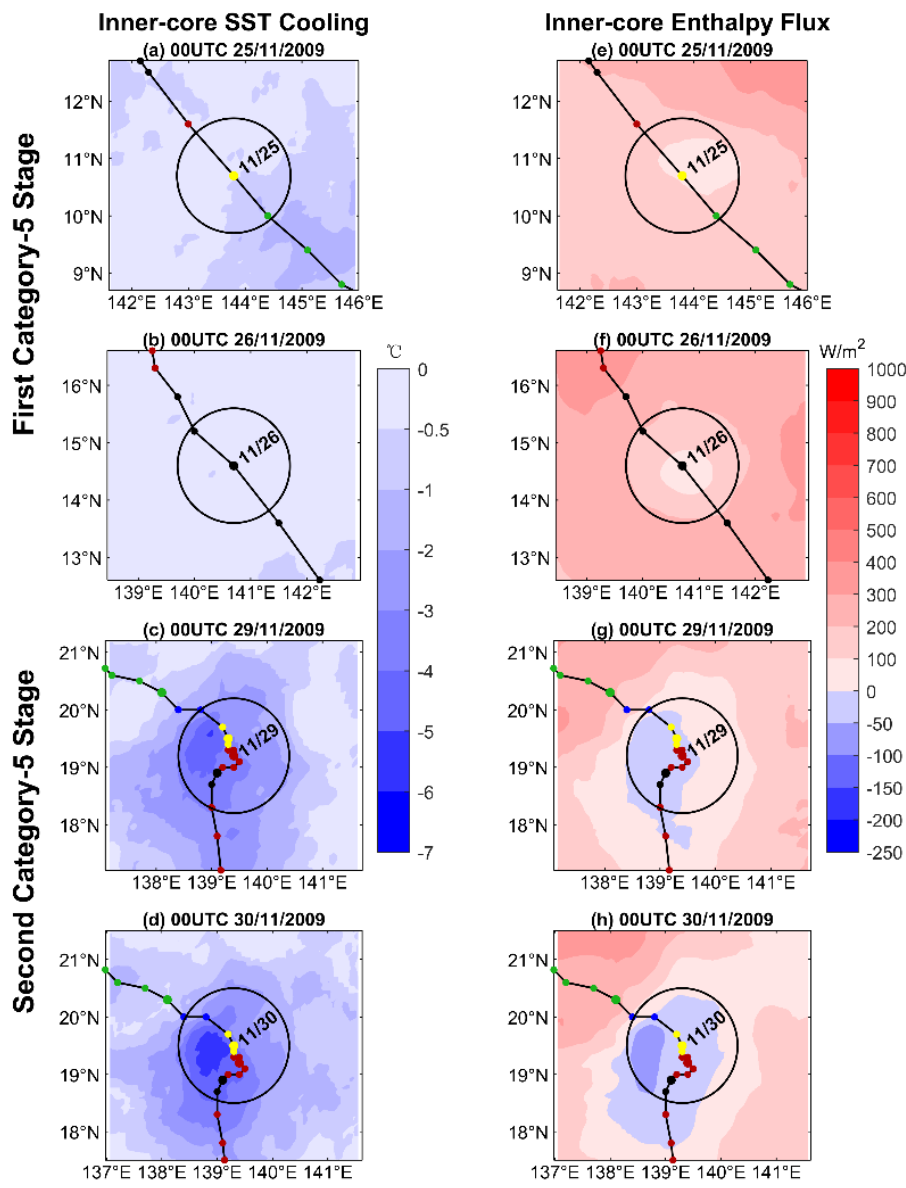

Figure 8. Evolution of the inner-core SST cooling (shaded, ${ }^{\circ} \mathrm{C}$ ) and inner-core enthalpy flux (shaded, $\mathrm{W} \mathrm{m}^{-2}$ ) in the SL stage and ST stage. The black solid circle represents the radius of $100 \mathrm{~km}$ from the typhoon, indicating its inner core.

Figure 9 shows the change in the typhoon turning angle (a), translation speed (b), inner-core SST cooling and local $\triangle$ SST wake (c), enthalpy flux and frictional flux (d), input power and net power (e) during the lifecycle of typhoon Nida. Meanwhile, the feedback factor $\mathrm{F}_{\mathrm{sst}}$ and the center pressure depression $(\Delta \mathrm{Pc})$ of Nida [19] were calculated and the results are presented in Figure 9f,g. $\mathrm{F}_{\mathrm{sst}}$ means the negative feedback level of cold wake to typhoon, the closer $\mathrm{F}_{\mathrm{sst}}$ is to -1 , the greater the negative feedback of cold wake is. During 22-24 November, Nida turned left (Figure 9a) and moved at a speed of about $2 \mathrm{~m} \mathrm{~s}^{-1}$ (Figure 9b). The local cold wake, inner-core SST cooling caused by Nida (Figure 9c), and the energy input from the ocean into the typhoon (Figure 9d,e) were very weak due to the weak SSW. The feedback factor $\mathrm{F}_{\mathrm{sst}}$ was relatively strong because Nida moved slowly along the turning track (Figure 9f). Therefore, due to weak energy from the ocean and strong F $_{\text {sst}}$, Nida's intensity strengthened slowly (Figure 9g) during this time.

On 24 November, Nida strengthened to typhoon intensity and evolved into the SL stage. In the SL stage, the typhoon track of Nida was close to a straight line (Figure 9a) and the maximum translation speed reached $6.4 \mathrm{~m} \mathrm{~s}^{-1}$ (Figure $9 \mathrm{~b}$ ), as shown by the blue line segment in Figure 9. Because Nida moved along a straight-line track and the speed was fast, the local cold wake caused by the typhoon was very weak (Figure 9c). As the speed gradually slowed to $4 \mathrm{~m} \mathrm{~s}^{-1}$, the typhoon-induced local cold wake gradually strengthened to $3{ }^{\circ} \mathrm{C}$. Cione and Uhlhorn [14] showed that it took $23 \mathrm{~h}$ for the background water temperature to change into a cold wake. Assuming that the radius of the cold wake was $100 \mathrm{~km}$, if the inner-core area was to feel the cold wake, the speed of the typhoon should be slower than $2 \mathrm{~m} \mathrm{~s}^{-1}$. Therefore, when the speed of the typhoon slowed to $4 \mathrm{~m} \mathrm{~s}^{-1}$, although the typhoon-induced local cold wake gradually strengthened, the inner-core SST 
cooling was still weak. The environment in the inner-core area still provided favorable conditions for the development of the typhoon. In this stage, the enthalpy flux supplied by the ocean to the typhoon increased to $1000 \mathrm{~W} \mathrm{~m}^{-2}$ (Figure $9 \mathrm{~d}$ ), and the corresponding input power (and net power) from the tropical ocean to Nida increased to 500 (200) $\mathrm{W} \mathrm{m}^{-2}$ (Figure 9e). The feedback factor Fsst of Nida in this stage was very weak, with a value above -0.4 (Figure 9f). Therefore, because of the strong energy from the ocean and weak Fsst, Nida intensified rapidly to a Category 5 typhoon with a $\Delta \mathrm{Pc}$ of $99 \mathrm{hPa}$ and MSW speed of $155 \mathrm{kts}$, and the intensification rate was about three times the definition of rapid intensification in previous studies (Figure $9 \mathrm{~g}$ ).

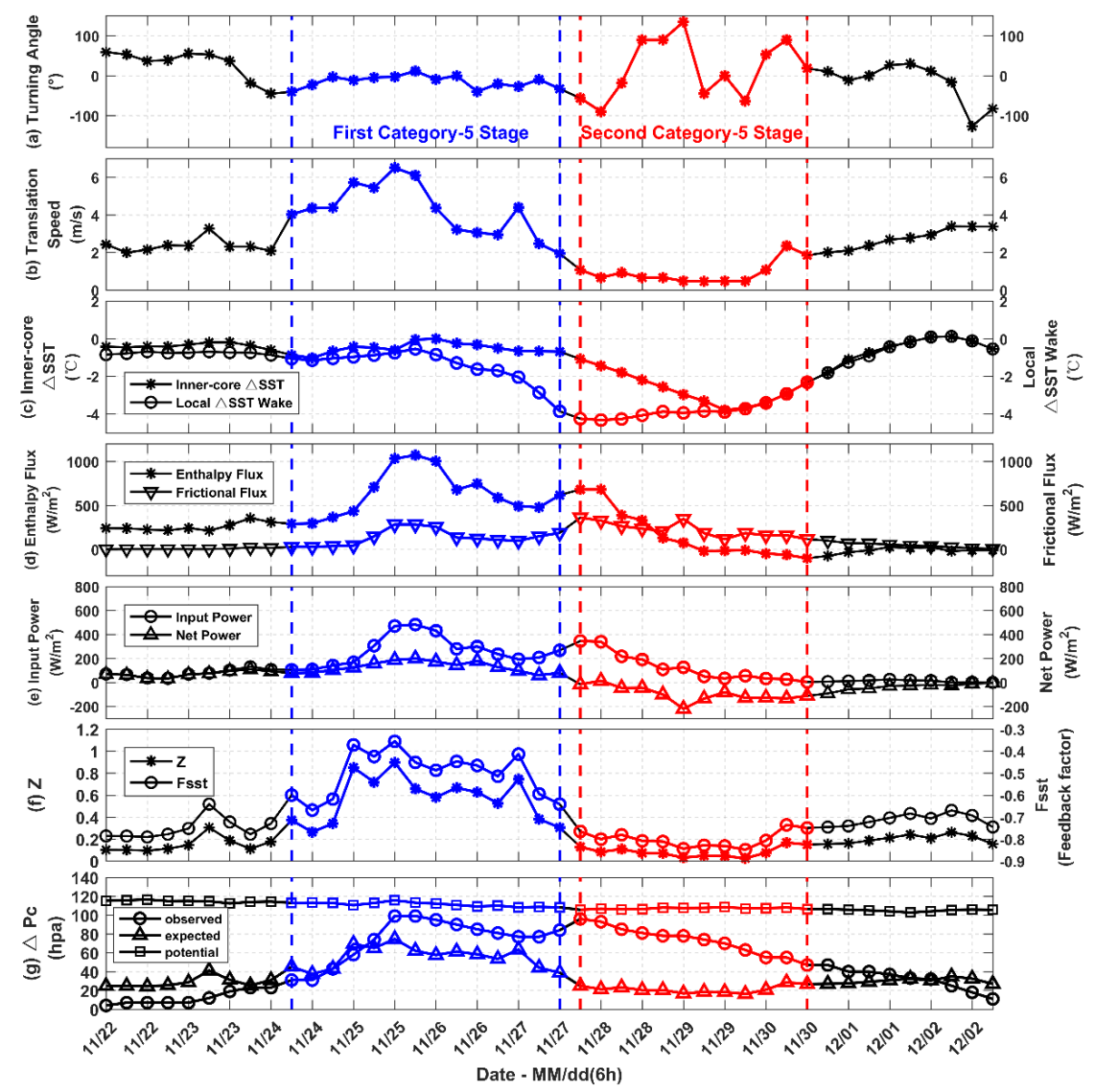

Figure 9. The (a) turning angle $\left(^{\circ}\right),(\mathbf{b})$ translation speed $\left(\mathrm{m} \mathrm{s}^{-1}\right),(\mathbf{c})$ inner-core SST cooling and local $\triangle$ SST wake $\left({ }^{\circ} \mathrm{C}\right),(\mathbf{d})$ enthalpy flux and frictional flux $\left(\mathrm{W} \mathrm{m}^{-2}\right),(\mathbf{e})$ input power and net power $(\mathrm{W}$ $\mathrm{m}^{-2}$ ), (f) feedback factor Fsst and reference value Z in Schade and Emanuel (1999), and (g) observed, expected and potential pressure depression in the eye of typhoon Nida during its passage. The blue and red segments indicate the straight-line stage and the sudden-turning stage of typhoon Nida, respectively.

On 27 November, Nida suddenly turned left and evolved into the ST stage. In the ST stage, the typhoon moved very slowly (about $1 \mathrm{~m} \mathrm{~s}^{-1}$ ), especially during suddenturning (Figure 9a,b), as shown by the red line segment in Figure 9. Owing to the cyclonic sharp turning and extremely slow speed, the typhoon caused a strong cold wake of $4{ }^{\circ} \mathrm{C}$ (Figure 9c). At the same time, the sharp turning and slow speed resulted in the typhoon center revisiting and staying over the cold wake, and the inner-core SST cooling began to drop rapidly to $4{ }^{\circ} \mathrm{C}$. The decrease in the inner-core SST resulted in a rapid decrease in the enthalpy flux supplied by the ocean to Nida (Figure 9d), and the corresponding input power (and net power) decreased to $50(-200) \mathrm{W} \mathrm{m}^{-2}$ (Figure 9e). The feedback factor Fsst strengthened rapidly to -0.85 because of Nida's extremely slow translation speed along the sudden-turning track (Figure 9f). As shown in Figure 9g, Nida weakened from 
Category 5 with a $\Delta \mathrm{Pc}$ of $96 \mathrm{hPa}$, to Category 2 with a $\Delta \mathrm{Pc}$ of $55 \mathrm{hPa}$ before and after the ST stage. In summary, owing to the different motions of typhoon Nida in the different stages, the ocean's responses and feedbacks to the typhoon were quite different in the different stages.

\section{Discussion}

This study used multiple satellite observations to study typhoon-ocean interactions: left bias ocean responses purely due to sharp-left sudden-turning of typhoon; resulting in more in-tense marine biological and physical responses and negative feedback; such negative feedback could only work under very restricted conditions with typical translation speed $<2 \mathrm{~m} \mathrm{~s}^{-1}$. However, the coarseness of the spatial and temporal resolutions of these data might have limited our findings. Given the nature of the strong atmospheric forcing associated with the sharp gradient from a super typhoon, high temporal and spatial resolution analyses and comparisons are certainly preferable in order to investigate the oceanic responses and feedbacks in sufficient detail. This requires the development of new techniques to obtain higher spatial and temporal resolution data. NOAA already has a successful program of hurricane observation and in situ data collection from airplanes inside hurricanes that provide high-resolution data, so the new techniques have already been developed. The problem is the cost of it.

Although there were negative feedbacks to typhoon Nida's intensity, the statistical regression of feedback $F_{\text {sst }}$ [19] was several times larger than the measured intensity change, as shown in Figure 9. The overestimation of the feedback $F_{\text {sst }}$ might have resulted in overestimation of the negative feedback time. The feedback $F_{\text {sst }}$ was obtained from statistical regression of the steady-state intensity of the hurricane in model simulations. According to numerical simulations [16,19], it takes a storm more than two to three days to settle into a statistically steady state in coupled models. This time in general is much longer than the interaction time between a typhoon and ocean cold wake. Thus, the negative feedbacks were too weak to be noted in observations.

Although the negative feedbacks were generally too weak to kill the typhoon, they may have suppressed the typhoon's intensity, as in Figure 9g. Typhoon Nida is not an isolated case. For typhoon Hagibis in 2007 [18], and typhoon Prapiroon in 2012 [56], their curved typhoon tracks caused them to undergo a similar process: generation and revisiting of a cold eddy, and the negative feedback process suppressed their intensity to below Category 1. The differences of the three typhoons are: 1. Hagibis and Prapiroon only reached the Category 1 typhoon intensity, while Nida reached the Category 5 typhoon intensity, which is more destructive; 2 . The negative feedback effect of cold wake on Hagibis and Prapiroon is to suppress the development of typhoon, while the cold wake resulted in the rapid weakening of typhoon Nida, from Category 5 typhoon to Category 2 typhoon. The research of super typhoon Nida is more important for predicting the rapid weakening of super typhoons.

Besides, we considered which parameter might be dominant, although the negative feedback factor $z$ includes many parameters, such as SST, ocean MLD, ocean stratification, typhoon translation speed, typhoon size, latitude, and so on [19]. This can be seen from Figure $9 b, f$, in which both curves have similar variation and their correlation is 0.85 . This implies that the dominant parameter of negative feedback was translation speed in the case of typhoon Nida. This is consistent with the results of past studies [17], which indicate that mostly slow-moving TCs experience negative feedback that can be more or less pronounced depending on the ocean stratification (e.g., the depth of the $26{ }^{\circ} \mathrm{C}$ isotherm).

The sharp sudden-turning track is an effective way of slowing the translation speed. When the typhoon moves along a straight-line track, it needs to move at a very slow speed $\left(<2 \mathrm{~m} \mathrm{~s}^{-1}\right)$ for a significant negative feedback, which is restricted by the radius of the typhoon core and cold wake. According to statistical analysis, in the North Atlantic, for about $15 \%$ of the duration of a hurricane, the speed is below $2 \mathrm{~m} \mathrm{~s}^{-1}$, and only $3 \%$ of the time is below $1 \mathrm{~m} \mathrm{~s}^{-1}$ [57]; in the Pacific Ocean, the proportion of time below $2 \mathrm{~m} \mathrm{~s}^{-1}$ may 
be as low as 10\% [27]. According to our statistical analysis, only $6 \%$ of typhoons in the NWP moved slower than $2 \mathrm{~m} \mathrm{~s}^{-1}$ in the past 40 years from 1981 to 2018, while the proportion below $1 \mathrm{~m} \mathrm{~s}^{-1}$ was as low as $1 \%$ (Figure 10a). Therefore, for a typhoon that moves in a straight line at a typical speed $\left(4-6 \mathrm{~m} \mathrm{~s}^{-1}\right)$, even if there is a decrease in SST, negative feedback barely exists [12]. However, when a typhoon moves along a sudden-turning track, the equivalent speed of the typhoon is greatly reduced, which is equivalent to the typhoon staying in a specific area for a longer time, increasing the probability of negative feedback. Therefore, sharp sudden-turning could effectively relax restrictions by making equivalent translation speed lower and air-sea interaction time longer. According to the angle statistics (Figure 10b), more than $60 \%$ of typhoons are close to straight (amplitude of turning angle $<20^{\circ}$ ), and due to the influence of the NWP subtropical high pressure and large-scale circulation, more than $60 \%$ of typhoons turn right. Note in particular, the proportion of typhoons with a turning angle greater than $50^{\circ}$ is about $10 \%$, which can increase the probability that a typhoon will revisit the cold wake, thus enhancing the negative feedback effect that is difficult to trigger.

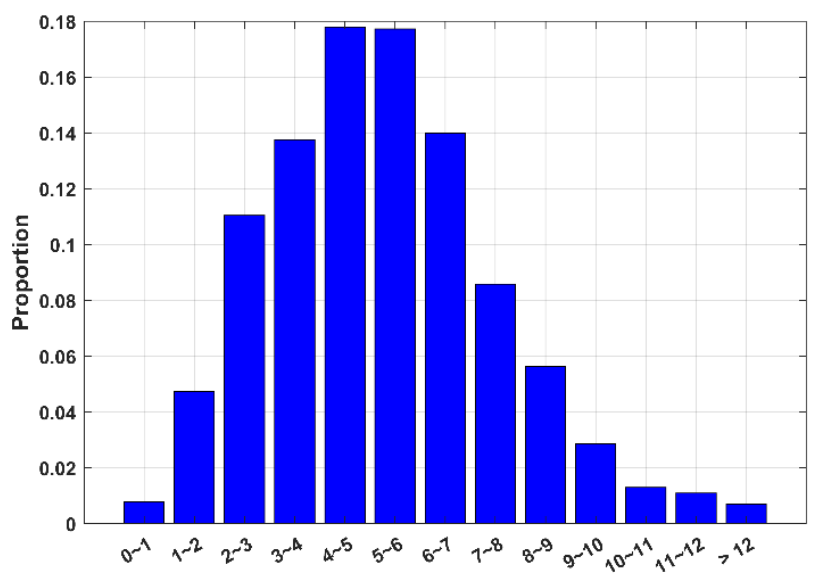

(a) Translation Speed $(\mathrm{m} / \mathrm{s})$

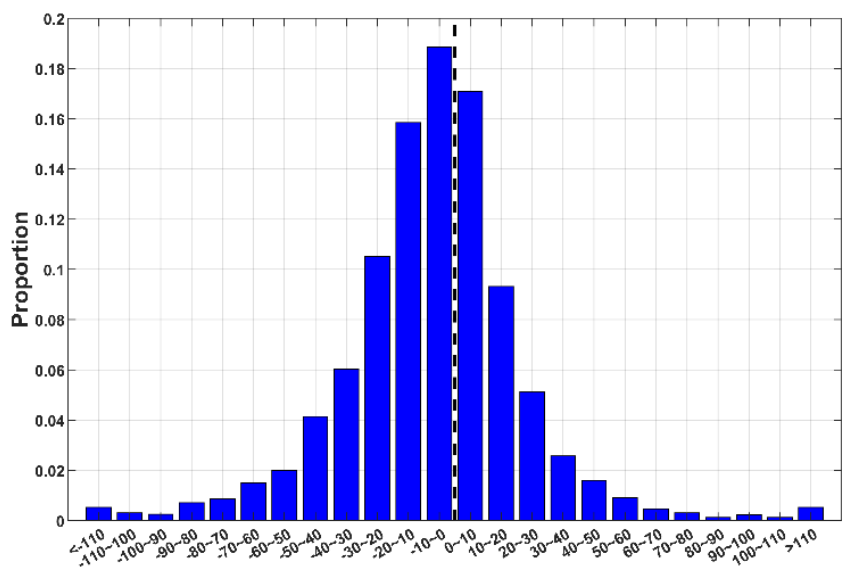

(b) Turning Angle (degree)

Figure 10. Distribution of typhoon (a) translation speed and (b) turning angle in the NWP during the 40 years from 1981 to 2018.

\section{Conclusions}

The ocean surface and subsurface biophysical responses and their feedbacks to super typhoon Nida were comprehensively investigated based on a substantial dataset of multiple-satellite observations, Argo profiles, and reanalysis data. Super typhoon Nida generated in the NWP in 2009 and consisted of two Category 5 stages. In the straight-line stage, Nida moved quickly along a straight-line track and rapidly intensified from Category 1 to Category 5. In the sudden-turning stage, Nida moved slowly along a sharp-left sudden-turning track and weakened from Category 5 to Category 2. Summarizing the regularity of typhoon-ocean interaction under different typhoon motions can provide a comprehensive and in-depth understanding of the typhoon-ocean interaction process. Based on this study, a schematic illustration of the interaction between the typhoon and the ocean, including the SL stage and the ST stage, is shown in Figure 11.

In the SL stage (24-27 November), Nida moved fast and along a straight northwest line, and the intensity strengthened rapidly from 65 to $155 \mathrm{kts}$. The strong winds induced strong vertical mixing and Ekman pumping. However, Nida caused only weak SST cooling because of the straight-line track and fast speed. As it slowed below $4 \mathrm{~m} \mathrm{~s}^{-1}$, the ocean response gradually strengthened. During the whole stage, Nida induced an average SST cooling of $1.44{ }^{\circ} \mathrm{C}$, an SSHA response of $-5.00 \mathrm{~cm}$, and a chl-a response of $0.03 \mathrm{mg} \mathrm{m}^{-3}$. Meanwhile, Nida's inner-core SST cooling was weaker than $0.5^{\circ} \mathrm{C}$ due to the fast speed along a straight-line track. Consequently, the enthalpy flux supplied from the ocean to the 
typhoon remained at a high level, with a maximum flux exceeding $1000 \mathrm{~W} \mathrm{~m}^{-2}$, which intensified Nida from Category 1 to Category 5.

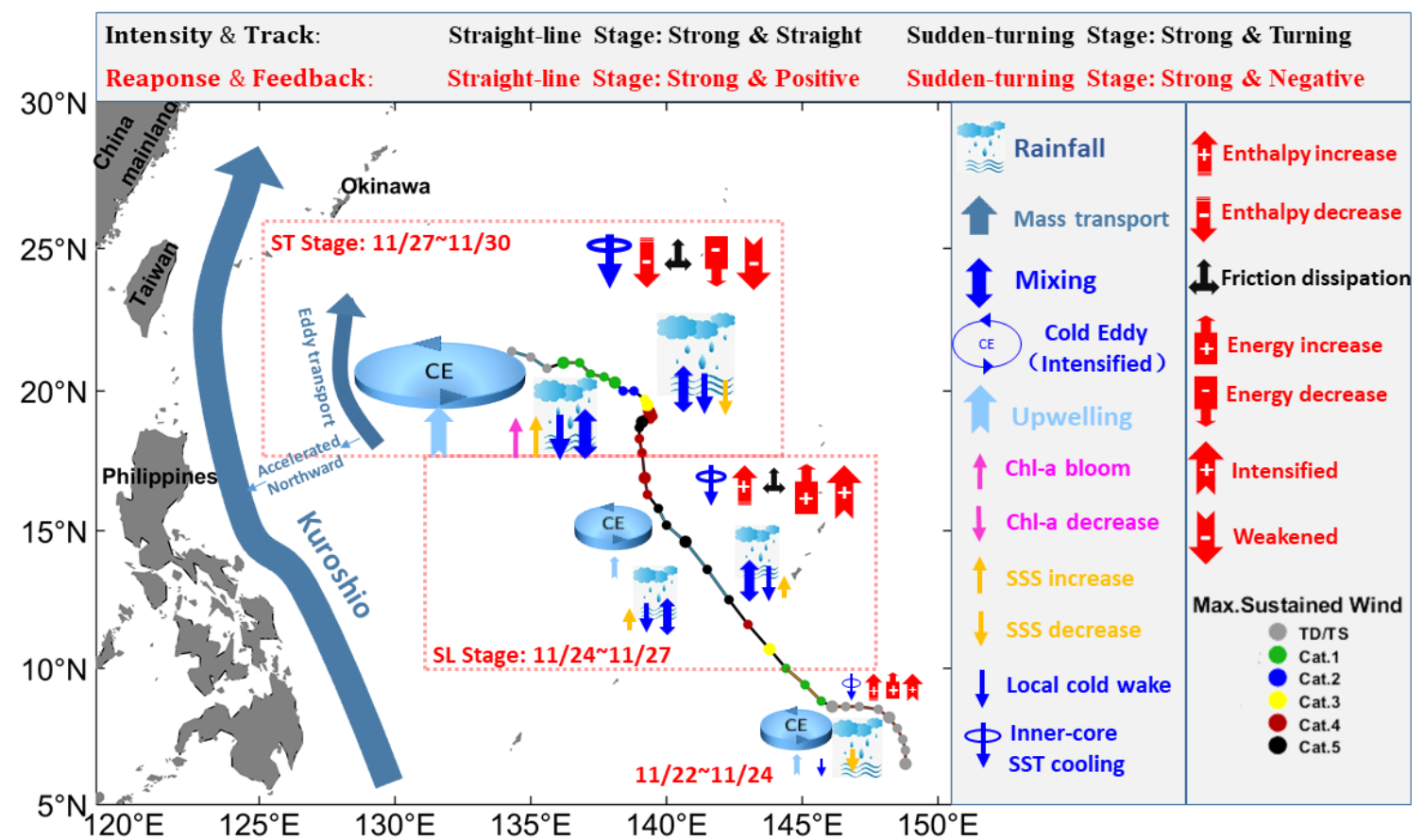

Figure 11. Schematic illustration of the interaction between super typhoon Nida and the ocean environment.

In the ST stage (27-30 November), Nida suddenly turned left, with a maximum left sudden-turning angle of $135^{\circ}$, and its translation speed was slower than $1 \mathrm{~m} \mathrm{~s}^{-1}$. Owing to the cyclonic sudden-turning and longer air-sea interaction time on the left-hand side of the track, Nida induced strong left bias ocean responses, which was a new phenomenon not reported and explained before. The average SST response, SSHA response and chl-a response was $-4.15^{\circ} \mathrm{C},-10.29 \mathrm{~cm}$, and $0.12 \mathrm{mg} \mathrm{m}^{-3}$, which was three times, two times, and four times more than those in the SL stage, respectively. Nida also induced a strong cold eddy (SSHA $<-60 \mathrm{~cm}$, maximum SST cooling $>6.68^{\circ} \mathrm{C}$ ), which caused a chl-a bloom exceeding $0.6 \mathrm{mg} \mathrm{m}^{-3}$ (more than five times) that lasted for weeks, which had significant impacts on the upper-ocean ecological environment. This strong cold eddy also potentially enhanced the Kuroshio Current as it approached the current, accelerating it by about $0.25 \mathrm{~Sv}$. The strong oceanic responses in turn induced a negative feedback effect on Nida's intensity. The average inner-core SST cooling of Nida reached $4{ }^{\circ} \mathrm{C}$, which resulted in a dramatic decrease in the sensible and latent heat fluxes at the sea-air interface from 681.9 to $-101.2 \mathrm{~W} \mathrm{~m}^{-2}$. Then, the sharp decrease in the enthalpy flux terminated the net energy supply from the ocean to the typhoon and further continually weakened the intensity of Nida from 150 (Category 5) to $90 \mathrm{kts}$ (Category 2) within three days.

It is concluded that the ocean response is weak when the typhoon intensity is weak or the typhoon speed is fast $\left(>6 \mathrm{~m} \mathrm{~s}^{-1}\right)$ along a straight-line track and the ocean response is much stronger when the typhoon intensity is stronger and the speed is slower $\left(\sim 4 \mathrm{~m} \mathrm{~s}^{-1}\right)$, which aligns with previous studies $[2,17,58,59]$. However, the ocean negative feedback to the typhoon intensity needs stricter conditions. According to the present case, the ocean negative feedback requires the typhoon to move at a slow speed $\left(<2 \mathrm{~m} \mathrm{~s}^{-1}\right)$; otherwise, the inner core of the typhoon cannot feel the local SST cooling, and the negative feedback might be negligible. Comparing with the previously found slow translation speed $\left(\sim 4 \mathrm{~m} \mathrm{~s}^{-1}\right)$ of significant ocean response, the negative feedback requires even more restriction of translation speed $\left(<2 \mathrm{~m} \mathrm{~s}^{-1}\right)$ and sharp sudden-turning could effectively relax restrictions by making equivalent translation speed lower and air-sea interaction time longer. In addition, the negative feedback of the ocean may weaken and/or suppress the typhoon 
intensity. However, such negative feedback may not be as strong as that suggested in previous studies. This might be due to the fact that SST is not the only factor affecting typhoon intensity. Other factors (including, for example, atmospheric conditions, the interaction between the typhoon and land) may also have roles [19].

Supplementary Materials: The following are available online at https: / www.mdpi.com/article / 10.3390/rs13142648/s1, Figure S1: The wind fields at $10 \mathrm{~m}$ (arrows) and the Ekman pumping velocity (shaded, positive value is upwelling) during the passage of Typhoon Nida (22 November-1 December 2009). The track line color indicated the max-sustained wind. Figure S2: Evolution of daily precipitation during the passage of typhoon Nida (22 November-1 December 2009). The track line color indicated the max-sustained wind. Figure S3: Evolution of daily SST (shaded, ${ }^{\circ} \mathrm{C}$ ) during the passage of typhoon Nida (22 November-3 December 2009). The track line color indicated the max-sustained wind. Figure S4: Evolution of the altimeter-derived SSHA (shaded, $\mathrm{cm}$ ) and surface geostrophic velocity (arrows) during the passage of typhoon Nida (22 November-3 December 2009). The track line color indicated the max-sustained wind of typhoon. Figure S5: Evolution of daily SSS (shaded, $\mathrm{cm}$ ) during the passage of typhoon Nida. The track line color indicated the max-sustained wind of typhoon (22 November-3 December 2009). Figure S6: (a-d) Evolution of weekly Chlorophyll concentration (shaded, $\left.\mathrm{mg} / \mathrm{m}^{3}\right),(\mathrm{e}-\mathrm{h})$ Evolution of weekly 2D fields of zooplankton (shaded, $\mathrm{g} / \mathrm{m}^{2}$ ) during the passage of typhoon Nida (17 November-18 December 2009). The track line color indicated the max-sustained wind of typhoon. Figure S7: Evolutions of mean SSHA within the cold eddy and the mass transport induced by the cold eddy on the left side of the track in the second Category 5 stage. Figure S8: Comparison of typhoon wind field and ocean condition on the left-hand and right-hand side if typhoon track in SL stage and ST stage respectively, extracted from Figures 3 and 4.

Author Contributions: Conceptualization, L.S.; data curation, J.L.; formal analysis, J.L. and L.S.; funding acquisition, L.S.; investigation, J.L.; methodology, J.L. and L.S.; writing-original draft, J.L.; writing-review and editing, J.L., Y.Y., G.W., H.C. and L.S. All authors have read and agreed to the published version of the manuscript.

Funding: This research was supported by the National Foundation of Natural Science of China (No. 41876013), the National Program on Global Change and Air-Sea Interaction (GASI-IPOVAI-04), the National Basic Research Program of China (2013CB430301 and 2013CB430303).

Institutional Review Board Statement: Not applicable.

Informed Consent Statement: Not applicable.

Data Availability Statement: Publicly available datasets were analyzed in this study. The daily SST data can be found here: [http:/ / data.remss.com/] (accessed on 1 April 2021). The daily SSS data can be found here: [http://marine.copernicus.eu/services-portfolio/access-to-products/] (accessed on 1 April 2021). The daily SSHA and sea surface geostrophic velocity data can be found here: [https: / / www.aviso.altimetry.fr/en/data/products/] (accessed on 1 April 2021). The wind vector datasets can be found here: [http://data.remss.com/] (accessed on 1 April 2021). The daily precipitation product can be found here: [https:// pmm.nasa.gov/data-access/downloads/gpm/] (accessed on 1 April 2021). Argo float profiles data can be found here: [http://www.argo.org.cn/] (accessed on 1 April 2021). Mixed-layer climatology and database can be found here: [http://mixedlayer.ucsd.edu/] (accessed on 1 April 2021). The daily and weekly ocean color datasets from GlobColour can be found here: [http:/ /hermes.acri.fr/index.php?class=archive] (accessed on 1 April 2021).

Acknowledgments: We thank Remote Sensing Systems for the SST and sea surface wind data (http:/ / www.remss.com/, (accessed on 1 April 2021)), GlobColour for chl-a product (http:/ / hermes. acri.fr/index.php?class=archive, (accessed on 1 April 2021)), National Aeronautics and Space Administration's Precipitation Processing System for the Integrated Multi-satellite Retrievals for GPM final precipitation product (https:/ / pmm.nasa.gov / data-access/downloads/gpm, (accessed on 1 April 2021)), Copernicus Marine and Environmental Monitoring Service Center for the SSS and zooplankton data (http:/ / marine.copernicus.eu/services-portfolio/access-to-products /, (accessed on 1 April 2021)), Archiving, Validation and Interpretation of Satellite Oceanographic for the SSHA and Geostrophic Velocity data (https:/ / www.aviso.altimetry.fr/en/data/products/, (accessed on 1 April 2021)), China Argo Real-time Data Center for Argo measurements (http:/ / www.argo.org.cn, (accessed on 1 April 2021)), and Scripps Institution of Oceanography, UC San Diego for MLD data (http:/ / mixedlayer.ucsd.edu/, (accessed on 1 April 2021)). 
Conflicts of Interest: The authors declare that they have no known competing financial interest or personal relationships that could have appeared to influence the work reported in this paper.

\section{References}

1. Price, J.F. Upper ocean response to a hurricane. J. Phys. Oceanogr. 1981, 11, 153-175. [CrossRef]

2. Vincent, E.M.; Lengaigne, M.; Madec, G.; Vialard, J.; Samson, G.; Jourdain, N.; Menkes, C.; Jullien, S. Processes setting the characteristics of sea surface cooling induced by tropical cyclones. J. Geophys. Res. Space Phys. 2012, 117, 117. [CrossRef]

3. Walker, N.D.; Leben, R.; Balasubramanian, S. Hurricane-forced upwelling and chlorophyllaenhancement within cold-core cyclones in the Gulf of Mexico. Geophys. Res. Lett. 2005, 32. [CrossRef]

4. Wang, G.; Wu, L.; Johnson, N.C.; Ling, Z. Observed three-dimensional structure of ocean cooling induced by Pacific tropical cyclones. Geophys. Res. Lett. 2016, 43, 7632-7638. [CrossRef]

5. Lin, I.-I.; Liu, W.T.; Wu, C.-C.; Wong, G.T.F.; Hu, C.; Chen, Z.; Liang, W.-D.; Yang, Y.; Liu, K.-K. New evidence for enhanced ocean primary production triggered by tropical cyclone. Geophys. Res. Lett. 2003, 30. [CrossRef]

6. Liu, Y.; Tang, D.; Evgeny, M. Chlorophyll Concentration Response to the Typhoon Wind-Pump Induced Upper Ocean Processes Considering Air-Sea Heat Exchange. Remote Sens. 2019, 11, 1825. [CrossRef]

7. Fisher, E.L. Hurricanes and the Sea-Surface Temperature Field. J. Meteorol. 1958, 15, 328-333. [CrossRef]

8. Leipper, D.F. Observed Ocean Conditions and Hurricane Hilda, 1964. J. Atmos. Sci. 1967, 24, 182-186. [CrossRef]

9. Stramma, L.; Cornillon, P.; Price, J.F. Satellite observations of sea surface cooling by hurricanes. J. Geophys. Res. Space Phys. 1986, 91, 5031-5035. [CrossRef]

10. Emanuel, K.A. An Air-Sea Interaction Theory for Tropical Cyclones. Part I-Steady-State Maintenance. J. Atmos. Sci. 1986, 43, 585-604. [CrossRef]

11. Emanuel, K. 100 Years of Progress in Tropical Cyclone Research. Meteorol. Monogr. 2018, 59, 15.1-15.68. [CrossRef]

12. Change, S.W.; Anthes, R.A. The mutual response of the tropical cyclone and the ocean. J. Phys. Oceanogr. 1979, 9, $128-135$. [CrossRef]

13. Sutyrin, G.; Khain, A. Effect of the Ocean-Atmosphere Interaction on the Intensity of a Moving Tropical Cyclone. Atmos. Ocean Sci. Lett. 1984, 20, 697-702.

14. Cione, J.J.; Uhlhorn, E.W. Sea Surface Temperature Variability in Hurricanes: Implications with Respect to Intensity Change. Mon. Weather. Rev. 2003, 131, 1783-1796. [CrossRef]

15. Emanuel, K.A. Thermodynamic control of hurricane intensity. Nat. Cell Biol. 1999, 401, 665-669. [CrossRef]

16. Ma, Z. A Study of the Interaction between Typhoon Francisco (2013) and a Cold-Core Eddy. Part I: Rapid Weakening. J. Atmos. Sci. 2020, 77, 355-377. [CrossRef]

17. Lin, I.-I.; Pun, I.-F.; Wu, C.-C. Upper-Ocean Thermal Structure and the Western North Pacific Category 5 Typhoons. Part II: Dependence on Translation Speed. Mon. Weather. Rev. 2009, 137, 3744-3757. [CrossRef]

18. Sun, L.; Yang, Y.-J.; Xian, T.; Lu, Z.-M.; Fu, Y.-F. Strong enhancement of chlorophyll a concentration by a weak typhoon. Mar. Ecol. Prog. Ser. 2010, 404, 39-50. [CrossRef]

19. Schade, L.R.; Emanuel, K.A. The Ocean's Effect on the Intensity of Tropical Cyclones: Results from a Simple Coupled AtmosphereOcean Model. J. Atmos. Sci. 1999, 56, 642-651. [CrossRef]

20. Bruneau, N.; Wang, S.; Toumi, R. Long Memory Impact of Ocean Mesoscale Temperature Anomalies on Tropical Cyclone Size. Geophys. Res. Lett. 2020, 47, 47. [CrossRef]

21. Lu, Z.; Wang, G.; Shang, X. Strength and Spatial Structure of the Perturbation Induced by a Tropical Cyclone to the Underlying Eddies. J. Geophys. Res. Oceans 2020, 125, 125. [CrossRef]

22. Wang, X.; Wang, C.; Zhang, L.; Wang, X. Multidecadal Variability of Tropical Cyclone Rapid Intensification in the Western North Pacific. J. Clim. 2015, 28, 3806-3820. [CrossRef]

23. Zheng, Z.-W.; Ho, C.-R.; Kuo, N.-J. Importance of pre-existing oceanic conditions to upper ocean response induced by Super Typhoon Hai-Tang. Geophys. Res. Lett. 2008, 35. [CrossRef]

24. Wentz, F.J. Satellite Measurements of Sea Surface Temperature through Clouds. Science 2000, 288, 847-850. [CrossRef]

25. Jaimes, B.; Shay, L.K.; Uhlhorn, E.W. Enthalpy and Momentum Fluxes during Hurricane Earl Relative to Underlying Ocean Features. Mon. Weather Rev. 2015, 143, 111-131. [CrossRef]

26. Powell, M.D.; Vickery, P.J.; Reinhold, T.A. Reduced drag coefficient for high wind speeds in tropical cyclones. Nat. Cell Biol. 2003, 422, 279-283. [CrossRef]

27. Lin, I.; Pun, I.; Lien, C.-C. "Category-6" supertyphoon Haiyan in global warming hiatus: Contribution from subsurface ocean warming. Geophys. Res. Lett. 2014, 41, 8547-8553. [CrossRef]

28. Mei, W.; Lien, C.-C.; Lin, I.-I.; Xie, S.-P. Tropical Cyclone-Induced Ocean Response: A Comparative Study of the South China Sea and Tropical Northwest Pacific. J. Clim. 2015, 28, 5952-5968. [CrossRef]

29. Brennan, M.J.; Hennon, C.C.; Knabb, R.D. The Operational Use of QuikSCAT Ocean Surface Vector Winds at the National Hurricane Center. Weather Forecast. 2009, 24, 621-645. [CrossRef]

30. Sun, J.; Oey, L.-Y. The Influence of the Ocean on Typhoon Nuri (2008). Mon. Weather. Rev. 2015, 143, 4493-4513. [CrossRef]

31. Li, J.; Sun, L.; Yang, Y.; Cheng, H. Accurate Evaluation of Sea Surface Temperature Cooling Induced by Typhoons Based on Satellite Remote Sensing Observations. Water 2020, 12, 1413. [CrossRef] 
32. Li, Q.-Y.; Sun, L.; Lin, S.-F. GEM: A dynamic tracking model for mesoscale eddies in the ocean. Ocean Sci. 2016, 12, 1249-1267. [CrossRef]

33. Liu, S.-S.; Sun, L.; Wu, Q.; Yang, Y.-J. The responses of cyclonic and anticyclonic eddies to typhoon forcing: The vertical temperature-salinity structure changes associated with the horizontal convergence/divergence. J. Geophys. Res. Oceans 2017, 122, 4974-4989. [CrossRef]

34. Sun, W.; Dong, C.; Tan, W.; He, Y. Statistical Characteristics of Cyclonic Warm-Core Eddies and Anticyclonic Cold-Core Eddies in the North Pacific Based on Remote Sensing Data. Remote Sens. 2019, 11, 208. [CrossRef]

35. Wang, G.; Ling, Z.; Wang, C. Influence of tropical cyclones on seasonal ocean circulation in the South China Sea. J. Geophys. Res. Space Phys. 2009, 114, 114. [CrossRef]

36. Zhang, Y.; Zhang, Z.; Chen, D.; Qiu, B.; Wang, W. Strengthening of the Kuroshio current by intensifying tropical cyclones. Science 2020, 368, 988-993. [CrossRef]

37. Wang, Z.-F.; Sun, L.; Li, Q.-Y.; Cheng, H. Two typical merging events of oceanic mesoscale anticyclonic eddies. Ocean Sci. 2019, 15, 1545-1559. [CrossRef]

38. Elsberry, S.A. Near-Inertial Ocean Current Response to Hurricane Frederic. J. Phys. Oceanogr. 1987, 17, $1249-1269$.

39. Huang, S.-M.; Oey, L.-Y. Right-side cooling and phytoplankton bloom in the wake of a tropical cyclone. J. Geophys. Res. Oceans 2015, 120, 5735-5748. [CrossRef]

40. Sun, L.; Yang, Y.-J.; Xian, T.; Wang, Y.; Fu, Y.-F. Ocean Responses to Typhoon Namtheun Explored with Argo Floats and Multiplatform Satellites. Atmos. Ocean 2012, 50, 15-26. [CrossRef]

41. Li, C.; Zhang, Z.; Zhao, W.; Tian, J. A statistical study on the subthermocline submesoscale eddies in the northwestern Pacific Ocean based on Argo data. J. Geophys. Res. Oceans 2017, 122, 3586-3598. [CrossRef]

42. Sun, L.; Li, Y.-X.; Yang, Y.-J.; Wu, Q.; Chen, X.-T.; Li, Q.-Y.; Li, Y.-B.; Xian, T. Effects of super typhoons on cyclonic ocean eddies in the western North Pacific: A satellite data-based evaluation between 2000 and 2008. J. Geophys. Res. Oceans 2014, 119, 5585-5598. [CrossRef]

43. Mei, W.; Primeau, F.; McWilliams, J.C.; Pasquero, C. Sea surface height evidence for long-term warming effects of tropical cyclones on the ocean. Proc. Natl. Acad. Sci. USA 2013, 110, 15207-15210. [CrossRef] [PubMed]

44. Jansen, M.F.; Ferrari, R.; Mooring, T. Seasonal versus permanent thermocline warming by tropical cyclones. Geophys. Res. Lett. 2010, 37, 15207-15210. [CrossRef]

45. Pujol, M.-I.; Faugère, Y.; Taburet, G.; Dupuy, S.; Pelloquin, C.; Ablain, M.; Picot, N. DUACS DT2014: The new multi-mission altimeter data set reprocessed over 20 years. Ocean Sci. 2016, 12, 1067-1090. [CrossRef]

46. Ciani, D.; Rio, M.-H.; Nardelli, B.B.; Etienne, H.; Santoleri, R. Improving the Altimeter-Derived Surface Currents Using Sea Surface Temperature (SST) Data: A Sensitivity Study to SST Products. Remote Sens. 2020, 12, 1601. [CrossRef]

47. Lomas, M.; Moran, S.; Casey, J.; Bell, D.; Tiahlo, M.; Whitefield, J.; Kelly, R.; Mathis, J.; Cokelet, E. Spatial and seasonal variability of primary production on the Eastern Bering Sea shelf. Deep. Sea Res. Part II Top. Stud. Oceanogr. 2012, 65-70, 126-140. [CrossRef]

48. Liu, S.; Li, J.; Sun, L.; Wang, G.; Tang, D.; Huang, P.; Yan, H.; Gao, S.; Liu, C.; Gao, Z.; et al. Basin-wide responses of the South China Sea environment to Super Typhoon Mangkhut (2018). Sci. Total Environ. 2020, 731, 139093. [CrossRef] [PubMed]

49. Huang, J.; Xu, F. Observational Evidence of Subsurface Chlorophyll Response to Mesoscale Eddies in the North Pacific. Geophys. Res. Lett. 2018, 45, 8462-8470. [CrossRef]

50. Lin, Y.-C.; Oey, L.-Y. Rainfall-enhanced blooming in typhoon wakes. Sci. Rep. 2016, 6, 31310. [CrossRef]

51. Sriver, R.L.; Huber, M. Observational evidence for an ocean heat pump induced by tropical cyclones. Nat. Cell Biol. 2007, 447, 577-580. [CrossRef]

52. Chen, D.; Lei, X.; Han, G.; Wang, W.; Zhou, L.; Wang, G. Upper Ocean Response and Feedback Mechanisms to Typhoon. Adv. Earth Sci. 2013, 28, 1077-1086. [CrossRef]

53. Jullien, S.; Menkes, C.; Marchesiello, P.; Jourdain, N.; Lengaigne, M.; Koch-Larrouy, A.; Lefèvre, J.; Vincent, E.; Faure, V. Impact of Tropical Cyclones on the Heat Budget of the South Pacific Ocean. J. Phys. Oceanogr. 2012, 42, 1882-1906. [CrossRef]

54. Hsu, P.-C.; Ho, C.-R. Typhoon-induced ocean subsurface variations from glider data in the Kuroshio region adjacent to Taiwan. $J$. Oceanogr. 2018, 75, 1-21. [CrossRef]

55. Cione, J.J. The Relative Roles of the Ocean and Atmosphere as Revealed by Buoy Air-Sea Observations in Hurricanes. Mon. Weather. Rev. 2015, 143, 904-913. [CrossRef]

56. Li, Y.X.; Yang, Y.J.; Sun, L.; Fu, Y.F. The upper ocean environment responses to typhoon Prapiroon (2012). SPIE Asia-Pac. Remote Sens. 2014, 9261, 92610U. [CrossRef]

57. Yablonsky, R.M.; Ginis, I. Limitation of One-Dimensional Ocean Models for Coupled Hurricane-Ocean Model Forecasts. Mon. Weather Rev. 2009, 137, 4410-4419. [CrossRef]

58. D'Asaro, E.; Black, P.G.; Centurioni, L.R.; Chang, Y.-T.; Chen, S.S.; Foster, R.C.; Graber, H.C.; Harr, P.; Hormann, V.; Lien, R.-C.; et al. Impact of Typhoons on the Ocean in the Pacific. Bull. Am. Meteorol. Soc. 2014, 95, 1405-1418. [CrossRef]

59. Mei, W.; Pasquero, C.; Primeau, F. The effect of translation speed upon the intensity of tropical cyclones over the tropical ocean. Geophys. Res. Lett. 2012, 39, L07801. [CrossRef] 